\title{
Atmospheric circulation patterns, cloud-to-ground lightning, and locally intense convective rainfall associated with debris flow initiation in the Dolomite Alps of northeastern Italy
}

\author{
S. Jeffrey Underwood ${ }^{1}$, Michael D. Schultz ${ }^{2}$, Metteo Berti ${ }^{3}$, Carlo Gregoretti $^{4}$, Alessandro Simoni ${ }^{3}$, Thomas L. Mote ${ }^{5}$, \\ and Anthony M. Saylor ${ }^{1}$ \\ ${ }^{1}$ Georgia Southern University, Statesboro, Georgia, USA \\ ${ }^{2}$ CDM-Smith, Dallas, Texas, USA \\ ${ }^{3}$ University of Bologna, Bologna, Italy \\ ${ }^{4}$ University of Padova, Padua, Italy \\ ${ }^{5}$ University of Georgia, Athens, Georgia, USA
}

Correspondence to: S. Jeffrey Underwood (sjunderwood@georgiasouthern.edu)

Received: 16 August 2015 - Published in Nat. Hazards Earth Syst. Sci. Discuss.: 25 September 2015

Revised: 25 January 2016 - Accepted: 29 January 2016 - Published: 22 February 2016

\begin{abstract}
The Dolomite Alps of northeastern Italy experience debris flows with great frequency during the summer months. An ample supply of unconsolidated material on steep slopes and a summer season climate regime characterized by recurrent thunderstorms combine to produce an abundance of these destructive hydro-geologic events. In the past, debris flow events have been studied primarily in the context of their geologic and geomorphic characteristics. The atmospheric contribution to these mass-wasting events has been limited to recording rainfall and developing intensity thresholds for debris mobilization. This study aims to expand the examination of atmospheric processes that preceded both locally intense convective rainfall (LICR) and debris flows in the Dolomite region. $500 \mathrm{hPa}$ pressure level plots of geopotential heights were constructed for a period of 3 days prior to debris flow events to gain insight into the synoptic-scale processes which provide an environment conducive to LICR in the Dolomites. Cloud-to-ground (CG) lightning flash data recorded at the meso-scale were incorporated to assess the convective environment proximal to debris flow source regions. Twelve events were analyzed and from this analysis three common synoptic-scale circulation patterns were identified. Evaluation of CG flashes at smaller spatial and temporal scales illustrated that convective processes vary in their production of CF flashes (total number) and the spatial distribution of flashes can also be quite different between events
\end{abstract}

over longer periods. During the 60 min interval immediately preceding debris flow a majority of cases exhibited spatial and temporal colocation of LICR and CG flashes. Also a number of CG flash parameters were found to be significantly correlated to rainfall intensity prior to debris flow initiation.

\section{Introduction}

Debris flows occur with great frequency in the Alpine region of northeastern Italy (Tecca and Genevois, 2009; Arattano, 1997). In fact mass-wasting episodes including debris flows have occurred regularly in the Dolomite Alps since the last glacial maximum (Panizza, 1973; Soldati et al., 2004) and observational records of debris flows in northeastern Italy date to the mid-1800s (Bacchini and Zannoni, 2003). The occurrence of debris flow events in this region of complex terrain is heavily influenced by ubiquitous deposits of weathered source material on steep slopes and a climatological regime that includes frequent summer season thunderstorms that produce locally intense convective rainfall (LICR) (Rossa et al., 2010). For this study LICR is defined as spatially confined rainfall that occurs at rates that exceed the intensity threshold for initiating runoff-generated debris flows. Spatially confined rainfall is that in which fewer 
than three of the precipitation gauges in the mico-network deployed in a basin record rainfall of sufficient intensity to trigger debris flow.

People, property, and infrastructure in the valleys and along hill slopes in the region are exposed to an extreme risk for debris flow as the region experiences a frequent return interval. The estimated return interval for medium-size debris flows is estimated, from existing records, at one event every 2 to 3 years (Berti et al., 1999). The threat posed by debris flow is however not static and the risk associated with this hydrogeologic hazard may become more acute in the future as changing climate patterns in the Mediterranean region alter the thunderstorm climatology. Floris et al. (2010) suggests that over the past 2 decades processes that enhance convection in the Mediterranean region have intensified and this may portend a future with an increased frequency of LICR in areas of complex terrain. If this is in fact the case it is likely that both the frequency and intensity of debris flow events in this area will be altered. Because of the threat of increased frequency of LICR in Dolomite Alps there is a need to better understand the hydrometeorology of the debris flow hazard and a need to develop better warning and forecasting techniques for the region (Bodini and Cossu, 2010; Bacchinni and Zannoni, 2003).

\section{Background}

This study analyzes multiple debris flow events with the intent of highlighting relationships between atmospheric processes and hydrogeologic outcomes in a region of complex terrain. The study tests the hypothesis that common synopticscale flow regimes provide an environment conducive to convective rainfall and debris mobilization in the Dolomite Alps of northeastern Italy. A second hypothesis proposes that CG flash variables at the meso- $\beta$ scale are collocated in time and space with LICR during the period immediately preceding debris flow initiation. To test these hypotheses debris flow events are analyzed at multiple spatial and temporal scales. Through a combination of well-tested methods the large scale atmospheric flow patterns for each debris flow event day are identified and smaller-scale convective process are identified using CG flash observations.

Many researchers have confirmed the connection between LICR and debris flow initiation in the Dolomite Alps and at other locations around the globe (DeGraff et al., 2011; Bacchini and Zannoni, 2003; Cannon et al., 1998; Floris et al., 2010; Chen et al., 2013). The debris flow literature is also replete with studies that incorporate estimates of rainfall intensity proximal in space and time to debris flow initiation (Floris et al., 2010; Shieh et al., 2009; Cannon et al., 2008; Moody and Martin, 2001; Chen et al., 2005; Galgaro et al., 2005). These studies rely on surface-based rainfall observations near debris source regions and have proven effective in identifying rainfall intensity thresholds for mobilizing debris in regions prone to mass wasting.

The inclusion of upper-level atmospheric processes to evaluate the preconditions for debris flow generation has not been extensive, although Turkington et al. (2014) incorporated meteorological stability indices such as convective available potential energy (CAPE) and $700 \mathrm{hPa}$ moisture availability in a study of what the authors called "flash events" in the Alpine region of southern France. These flash events included both floods and debris flows. Underwood and Schultz (2004) utilized equivalent potential temperature $\left(\theta_{\mathrm{e}}\right)$ at various pressure levels to identify atmospheric preconditions to LICR and post-wildfire debris flows in the southwestern USA. The study of convective rainfall in regions of complex terrain has been the subject of numerous studies including Trapp et al. (2009), Schmidli et al. (2007), Chen et al. (2012), and Parajka et al. (2010), however these studies confine their findings to the processes associated with convective rainfall and do not associate these processes with debris flow initiation. The present study builds on the debris flow literature as well as previous research related to convective rainfall in complex terrain and expands the spatial and temporal context for analyzing the debris flow hazard.

\section{Study area}

The debris flow events central to this research occurred across five basins described in Gregoretti and Dalla Fontana (2008). These basins are in the northeastern sector of the Italian Alps. Here the highest peaks reach $3300 \mathrm{~m}$ above sea level and the alpine landscape is dominated by large dolomite massifs. Bedrock outcrops occupy large areas, especially at elevations higher than $1800 \mathrm{~m}$ where subvertical cliffs are common and vegetation is scarce or absent (Marchi et al., 2002).

The dolomite massif, with its topography made of cliffs and gorges, represents a source of abundant sediment production. As a result, scree slopes surround the rocky massif. Due to the action of multiple sediment transfer processes the talus deposits are thicker at the outlet of incisions and gorges. Talus is made of poorly sorted debris that includes a vast range of grain sizes, from metric boulders to silt-size particles (Berti et al., 1999; Gregoretti and Dalla Fontana, 2008) (Fig. 1).

Debris flows initiate in the upper part of scree slopes and transport sediments to the valley bottom where settlements and infrastructure are typically located. Debris flow triggering is initiated by rapidly concentrating precipitation in the steep rocky basins where there is an absence of soil and vegetation. High runoff discharge is abruptly delivered at the basin outlet where ephemeral channels are incised into scree-covered slopes. Debris flows originate along such channels whenever surface runoff is sufficient to mobilize loose channel-bed material (Berti and Simoni, 2005; Coe 


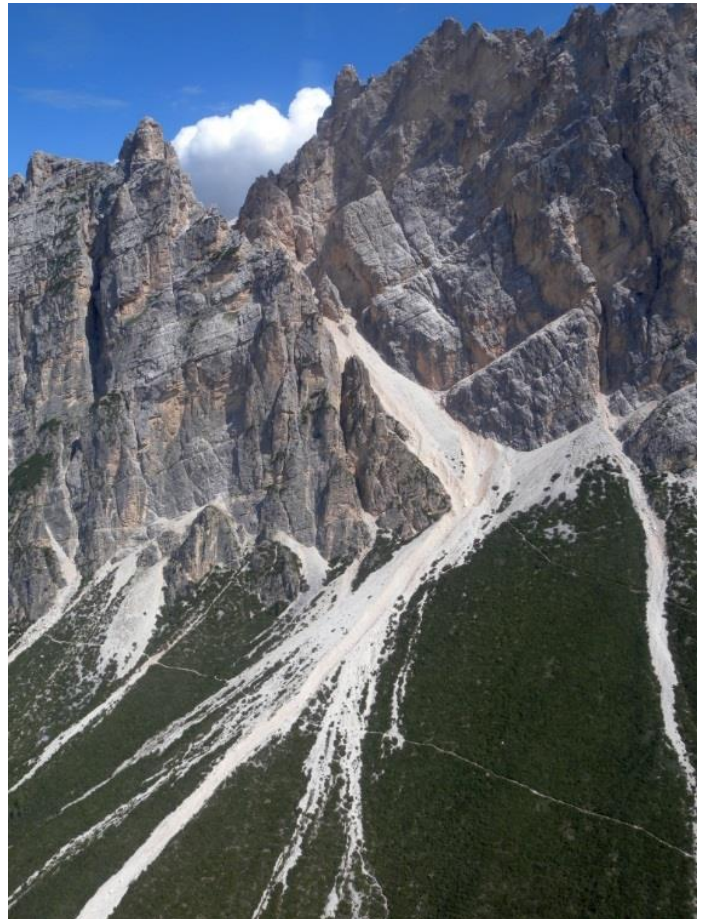

Figure 1. Dolomite massif with incised debris flow channel at study area in northeastern Italy.

et al., 2008; Hurlimann et al., 2014; Kean et al., 2013; Imaizumi et al., 2006). This mechanism of debris mobilization has been well documented by field monitoring (Berti et al., 2000; Tecca and Genevois, 2009) and also demonstrated in a laboratory setting (Gregoretti, 2000; Tognacca et al., 2000). Depending on sediment, water availability and channel morphology, entrainment can greatly enhance the volume of solid-liquid mixture that routes downstream and deposits on the fan (McCoy et al., 2012; Theule et al., 2012). The analysis of rainfall events which resulted in debris flow has produced regional rainfall thresholds for debris entrainment. Debris flow generating rainfall episodes typically have a duration of less than $30 \mathrm{~min}$ and a mean intensity that exceeds $0.3-0.5 \mathrm{~mm} \mathrm{~min}^{-1}$, which for the present study area grows up 0.8-1 $\mathrm{mm} \mathrm{min}^{-1}$ (Gregoretti and Dalla Fontana, 2008).

This study will employ analysis domains at the synoptic scale as well as the meso- $\alpha$ and meso- $\beta$ scales. The meso- $\alpha$ scale includes atmospheric processes with spatial dimensions of 200 to $2000 \mathrm{~km}$. The meso- $\beta$ scale refers to spatial dimensions of 20 to $200 \mathrm{~km}$. The nesting of analysis domains is illustrated in Fig. 2. The area for synoptic-scale atmospheric analysis is bounded by the following coordinates: 25 to $65^{\circ} \mathrm{N}$ latitude and $30^{\circ} \mathrm{W}$ to $40^{\circ} \mathrm{E}$ longitude. The meso- $\alpha$ analysis unit is bounded at 44 to $48^{\circ} \mathrm{N}$ and 7 to $15^{\circ} \mathrm{E}$. The meso- $\beta$ analysis unit is circular with a radius of $50 \mathrm{~km}$ and total area of $7850 \mathrm{~km}^{2}$. This particular meso- $\beta$ configuration has been used in previous studies of LICR and CG lightning flashes (Underwood and Schultz, 2004).

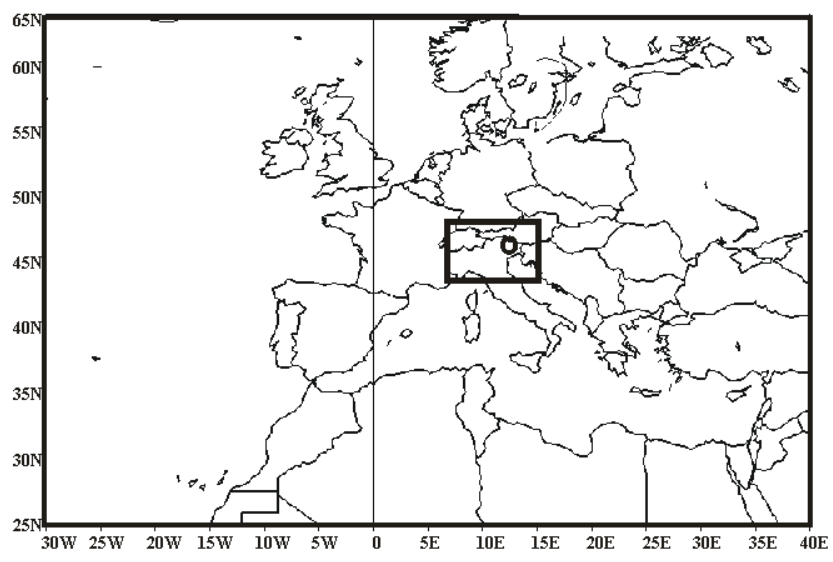

Figure 2. Nested view of study domains including the synoptic scale (the full domain as outline by the outer rectangle), meso$\alpha$ scale (denoted by the smaller rectangle encompassing northern Italy), and meso- $\beta$ scale (the smaller circle surrounding the debris flow source region). The debris flow basins for each of the 12 events are located in the meso- $\beta$ scale analysis unit.

Twelve debris flow events are analyzed in this study. The events actually occurred over five adjacent basins in the Dolomite Alps near Cortina d'Ampezzo, Italy. The authors simplify the representation of the basins by using a single "reference point" to indicate the position of the basins. The precise basins and locations can be obtained from Gregoretti and Dalla Fontana (2008). The coordinates for the basin reference point are $46.53^{\circ} \mathrm{N}, 12.13^{\circ} \mathrm{E}$ and this point is shown in the context of the meso- $\alpha$ and meso- $\beta$ spatial domains in Fig. 3.

\section{Data and methods}

Data incorporated in this research include gridded upperair data from freely available meteorological archives, fieldcollected rainfall data, and proprietary CG lightning flash data. The upper-air data sets include $500 \mathrm{hPa}$ geopotential height plots (geopotential height is the approximation of actual height of a pressure level above mean sea level), as well as $700 \mathrm{hPa}$ omega fields (omega is a calculated atmospheric parameter based on observation of both temperature advection and vorticity advection. The magnitude of omega is based on the magnitude of these two atmospheric observations. In general warm air advection and positive vorticity advection coinciding in space and time produces a negative omega value which suggests upward vertical motion). Additionally the lifted index will be used to assess regional stability conditions. The LI is an estimate of tropospheric stability, and is derived from a comparison of parcel temperature at $500 \mathrm{hPa}$ to the environmental temperature at the same level. If the parcel temperature has a higher temperature than the surrounding environment the result will be a negative value which suggest and unstable troposphere. The $500 \mathrm{hPa}$ pres- 


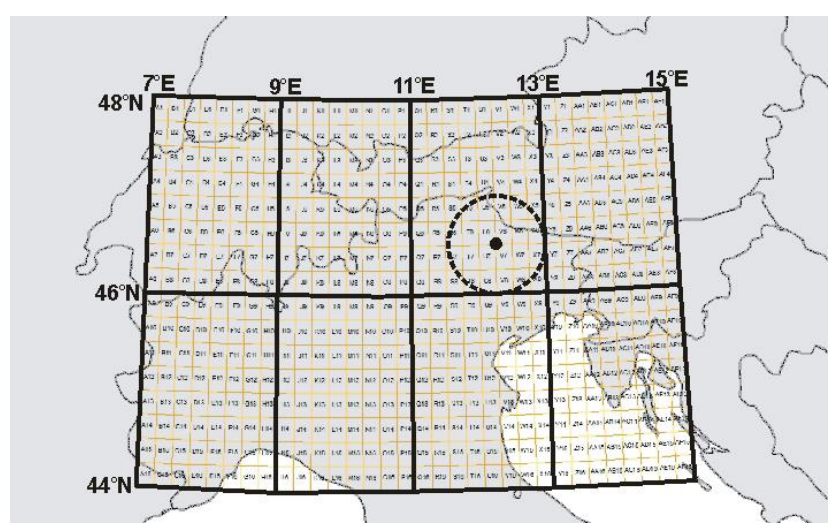

Figure 3. Debris flow basin reference point in context of meso-scale analysis domains. The bounding rectangle represents the meso- $\alpha$ scale and the circle (with $50 \mathrm{~km}$ radius) represents the meso- $\beta$ scale analysis unit. This meso- $\alpha$ scale also provides the spatial extent of the cloud-to-ground lightning data set used in the study. The labels in each grid are simple identifiers used in the mapping process, they do not represent any surficial or atmospheric variable.

sure level allows for the analysis of flow regime via the configuration of height contours. This level can also be used to identify horizontal divergence, which is the movement of air away from an identified point. $500 \mathrm{hPa}$ divergence may promote vertical motion from below the analyzed pressure level. Convergence at $500 \mathrm{hPa}$ measures the horizontal movement of air toward an identified point. Converging air at this level can promote downward vertical motion in the atmosphere below the analyzed pressure level. Absolute vorticity can also be diagnosed at the $500 \mathrm{hPa}$ level. Absolute vorticity can be defined as the "spin" present in the atmosphere and is the sum of earth vorticity (Coriolis) and relative vorticity (spin induced by shear flow and curved flow). Positive vorticity suggests counterclockwise spin in the Northern Hemisphere and is associated with rising vertical motion. Negative vorticity suggests clockwise spin in the atmosphere and is associated with downward vertical motion in the troposphere.

This study would not be possible without the identification of a discrete group of debris flow events. The events that form the foundation of the study conform to the following criteria: (1) debris flow initiation was witnessed by a reliable source; (2) the exact time of debris flow initiation was reported and archived; and (3) rainfall data from at least one precipitation gauge located proximal to the debris source region was available to the researchers. Proximal in this case refers to a precipitation gauge from 2 to $20 \mathrm{~km}$ from the debris flow source region. Ten debris flow events conforming to these standards were identified from a list published in Gregoretti and Dalla Fontana (2008). One may review the list of events in Table VII of the referenced publication. The reader should be mindful when viewing the table that only those events coded " $T$ WITNESS" were included in this study. Also the event times were converted to UTC so that this in- formation would conform to the time conventions of other data sets utilized. Two additional debris flow events which met the criteria, but were not listed in Gregoretti and Dall Fontana (2008), were identified by the authors and added to the population (Degetto et al., 2015). The strict observation criteria ensured that debris flow initiation could be analyzed in a temporally coincident fashion with data sets including local rainfall, CG lightning flashes, and upper atmospheric fields.

For each of the 12 debris flow events the authors collected a suite of data sets for analysis. Gridded data describing the upper atmosphere were obtained from the Earth System Research Laboratory NCEP/NCAR Reanalysis Project archive (Kalnay et al., 1996). These data were used to calculate and plot upper atmospheric fields at the synoptic scale and produce time series plots of selected fields. Note that in matching upper-air observations with the observed time of debris flow initiation a temporal adjustment was necessary. The upper-air gridded data are available at $6 \mathrm{~h}$ observation intervals (00:00, 00:60, 12:00 and 18:00 UTC). A temporal offset was used to match the upper-air observation to debris flow observation in each case. This was accomplished by selecting the upper-air observation nearest in time (UTC) to observed debris flows. The upper-air observation selected to represent each event is referred to as the "zero-hour" observation for purposes of developing a time series analysis. For example, a debris flow occurring at 17:10 UTC would be matched with the upper-air observation at 18:00 UTC and the upper-air time series analysis would use 18:00 UTC as the zero-hour. This convention for choosing the zero-hour may result in some events corresponding with synoptic observations occurring prior to debris flow observation, and others corresponding to synoptic observations that occur post debris flow. As the synoptic-scale flow has not only a larger spatial footprint than the meso-scale, it also has a broader temporal span and thus the error imparted into the analysis should be minimal. Using this convention $500 \mathrm{hPa}$ geopotential height plots were created for each event beginning with the zerohour. To complete the time series, upper-air data were processed for observations $24 \mathrm{~h}$ in advance of the zero-hour and $48 \mathrm{~h}$ in advance of the zero-hour. In discussing the upperatmospheric time series the abbreviations T-0, T-24, and T-48 will be used to represent the three observations. Online plotting tools for the reanalysis data are made available to the public by the NOAA/ESRL Physical

Sciences Division and were used in this study to produce single-event plots and composite plots.

CG lightning flash data were obtained from Centro Elettrotecnico Sperimentale Italiano - Sistema Italiano Rilevamento Fulmini (CESI-SIRF) (Iorio, 1998). The CESI-SIRF archive provides highly accurate CG flash location (latitude/longitude) as well as polarity (positive/negative) and amplitude in units kA for each CG flash. Table 1 lists the events by date, time of debris flow observation, zero-hour, and referenced source. 
Table 1. The population of 12 debris flow events.

\begin{tabular}{|c|c|c|}
\hline $\begin{array}{l}\text { Debris flow } \\
\text { event date }\end{array}$ & $\begin{array}{l}\text { Witness time/ } \\
\text { zero-hour }\end{array}$ & $\begin{array}{l}\text { Source of event } \\
\text { information }\end{array}$ \\
\hline 7 August 1996 & 19:00/18:00 UTC & Gregoretti and Della Fontana 2008 \\
\hline 12 June 1997 & 13:19/12:00 UTC & Gregoretti and Della Fontana 2008 \\
\hline 17 August 1998 & 19:21/18:00 UTC & Gregoretti and Della Fontana 2008 \\
\hline 20 July 1999 & 16:30/18:00 UTC & Gregoretti and Della Fontana 2008 \\
\hline 28 July 1999 & 14:40/12:00 UTC & Gregoretti and Della Fontana 2008 \\
\hline 20 September 1999 & 20:00/18:00 UTC & Gregoretti and Della Fontana 2008 \\
\hline 30 September 2000 & 16:45/18:00 UTC & Gregoretti and Della Fontana 2008 \\
\hline 30 June 2001 & 19:00/18:00 UTC & Gregoretti and Della Fontana 2008 \\
\hline 19 July 2004 & 17:30/18:00 UTC & Gregoretti and Della Fontana 2008 \\
\hline 5 July 2006 & 16:30/18:00 UTC & Gregoretti and Della Fontana 2008 \\
\hline 4 July 2011 & 20:45/18:00 UTC & Degetto et al. (2015) \\
\hline 18 August 2011 & 17:10/18:00 UTC & Degetto et al. (2015) \\
\hline
\end{tabular}

Rainfall observations were recorded by a meso-network of rainfall gauges installed across adjacent basins at a field site in the Dolomite Alps near the town of Cortina d'Ampezzo in northeastern Italy. The particular gauges utilized in this study are listed and described in Gregoretti and Dalla Fontana (2008) and Degetto et al. (2015). The rainfall data were recorded at $5 \mathrm{~min}$ intervals for each of the 12 event days. Parameters such as total accumulated rainfall, peak 5 min rainfall rate, and rainfall intensity were calculated from the observed data.

To classify synoptic-scale atmospheric patterns supporting LICR and debris flow initiation in northeastern Italy, $500 \mathrm{hPa}$ geopotential height observations for the 12 events were plotted and analyzed. The $500 \mathrm{hPa}$ pressure level serves as a very good indicator of general atmospheric flow patterns in the mid-troposphere. The $500 \mathrm{hPa}$ level is particularly useful in identifying Rossby wave patterns and areas of high and low pressure (as indicated by higher and lower geopotential heights). The size, position, amplitude, and tilt of waves as well as the position and movement of closed features and blocking configurations allows one to differentiate patterns and thus classify flow regimes. Pattern identification in the $500 \mathrm{hPa}$ height field using both manual and automated methods has been implemented with regularity to classify flow regimes at the synoptic scale. Further, flow regimes at this pressure level have been shown to coincide with surface meteorological and hydro-meteorological phenomena including intense rainfall, flooding, heavy snowfall, and dust storms (Hoard and Lee, 1986; Holle and Bennett, 1997; Mote et al., 1997; Hunter et al., 2001; Lapp et al., 2002; Underwood et al., 2009; Kaplan et al., 2013).

The synoptic-scale classification of events was operationalized by plotting a $48 \mathrm{~h}$ time series of $500 \mathrm{hPa}$ geopotential heights for each event and identifying via a manual rulesbased method the distinctive flow regimes. The rules for this classification were based on the comparison of the mean 30year flow regime to the flow regime of a single event. Higher geopotential heights were identified as ridges and areas with geopotential height lower than the 30-year mean were identified as troughs. Geopotential height contours that were truncated at a single value were defined as closed highs or closed lows. Blocking regimes were identified within the following rule structure. First, a high-pressure feature must be to the north of a low-pressure feature, and second, the features must be aligned within 10 degrees longitude - using center points as reference. Amplification was subjectively defined based on the shape and poleward or equatorward extend of the wave feature. After initial event reviews it was clear that there were in fact three common flow regimes (groups) represented in the population and that there was a very high degree of consistency in flow patterns within groups and a high degree of dissimilarity between groups. The pattern consistency was so striking that the authors decided to use a compositing technique to illustrate the $48 \mathrm{~h}$ time series for each classification. The composting technique computes mean grid values for upper-air variables (in this case $500 \mathrm{hPa}$ heights) and then plots contour lines based on the mean grid values. The atmospheric grids in this case are $2.5^{\circ} \times 2.5^{\circ}$ in size. The composite time series provides a detailed temporal and spatial analysis of the synoptic-scale features that define each group of events.

Following synoptic classification summary statistics were calculated for CG flash and rainfall variables for the population of debris flow events. The statistical analysis downscaled to the study to the meso- $\alpha$ and meso- $\beta$ scales. CG flash statistics were also calculated at three temporal scales - the $24 \mathrm{~h}$ that made up the debris flow event-day, the $6 \mathrm{~h}$ interval preceding debris flow initiation, which was estimated by the authors to be an ample temporal unit to capture stormtotal statistics, and the $60 \mathrm{~min}$ interval preceding debris flow initiation. The $60 \mathrm{~min}$ analysis further downscaled the analysis and identified processes related to a particular storm cell or cells that produced LICR and that were in the steep basins of the study area. Much of this analysis was based on iden- 
tifying peaks in CG flash activity. For this purpose a "peak" was defined as a 5 min flash frequency greater than one standard deviation above the mean. The mean in this case was calculated for the longest continuous flash sequence recorded at meso- $\beta$ scale.

CG lightning and rainfall data were examined using ESRI ArcGIS applications which allowed for both visualization of patterns and statistical analysis of the data. Particular applications included plotting CG flashes using latitude and longitude coordinates, and recovering data at various scales using point polygon extraction of flash attributes. Maps, graphics, and summary statistics were calculated for the CG flash data and rainfall observations using both ArcGIS and statistical software applications. Many of the statistics used in this study were designed and utilized in previous studies including Holle and Bennett (1997) and Underwood and Schultz $(2003,2004)$.

Correlation and lead-time analyses were conducted using atmospheric variables, CG flash variables, and rainfall intensity observations for the $60 \mathrm{~min}$ interval preceding debris flow. A Pearson product-moment correlation technique was employed to identify statistically significant relationships between multiple CG flash variables and rainfall intensity, thus linking observable flash characteristics to LICR at the meso$\beta$ scale (Hinkle et al., 2009).

The lead-time analysis as used in previous studies (Underwood and Schultz, 2004) calculates the time by which an observed variable precedes debris flow initiation. The mean value of the variable is then calculated across the population of events. The analysis of lead-time in this case was limited to the $60 \mathrm{~min}$ interval preceding debris flow initiation at the meso- $\beta$ scale. Only meso- $\beta$ scale variables were used in the lead-time analysis. The mean lead-time can be considered an indicator of a variable's potential as an alert parameter for debris flow warnings and forecasts.

\section{Analysis}

\section{$5.1500 \mathrm{hPa}$ geopotential height composites - sub-tropical high group}

Figure 4 illustrates the $48 \mathrm{~h}$ time series for the $500 \mathrm{hPa}$ geopotential height composites calculated using events from 7 August 1996, 12 June 1997, 17 August 1998, 20 July 1999, 30 June 2000, 19 July 2004, 18 August 2011, and 5 July 2006. The most prominent large-scale circulation feature from T-48 through T- 0 was an extensive sub-tropical high-pressure (height) center encompassing most of northern Africa with a persistent ridge extending into central Europe. This group of events will be referred to as the sub-tropical high group or STH for ease of discussion.

At T-48 the sub-tropical ridge at $500 \mathrm{hPa}$ was in place over northern Africa, as is common during the Mediterranean summer. The ridge of higher geopotential heights (illustrated

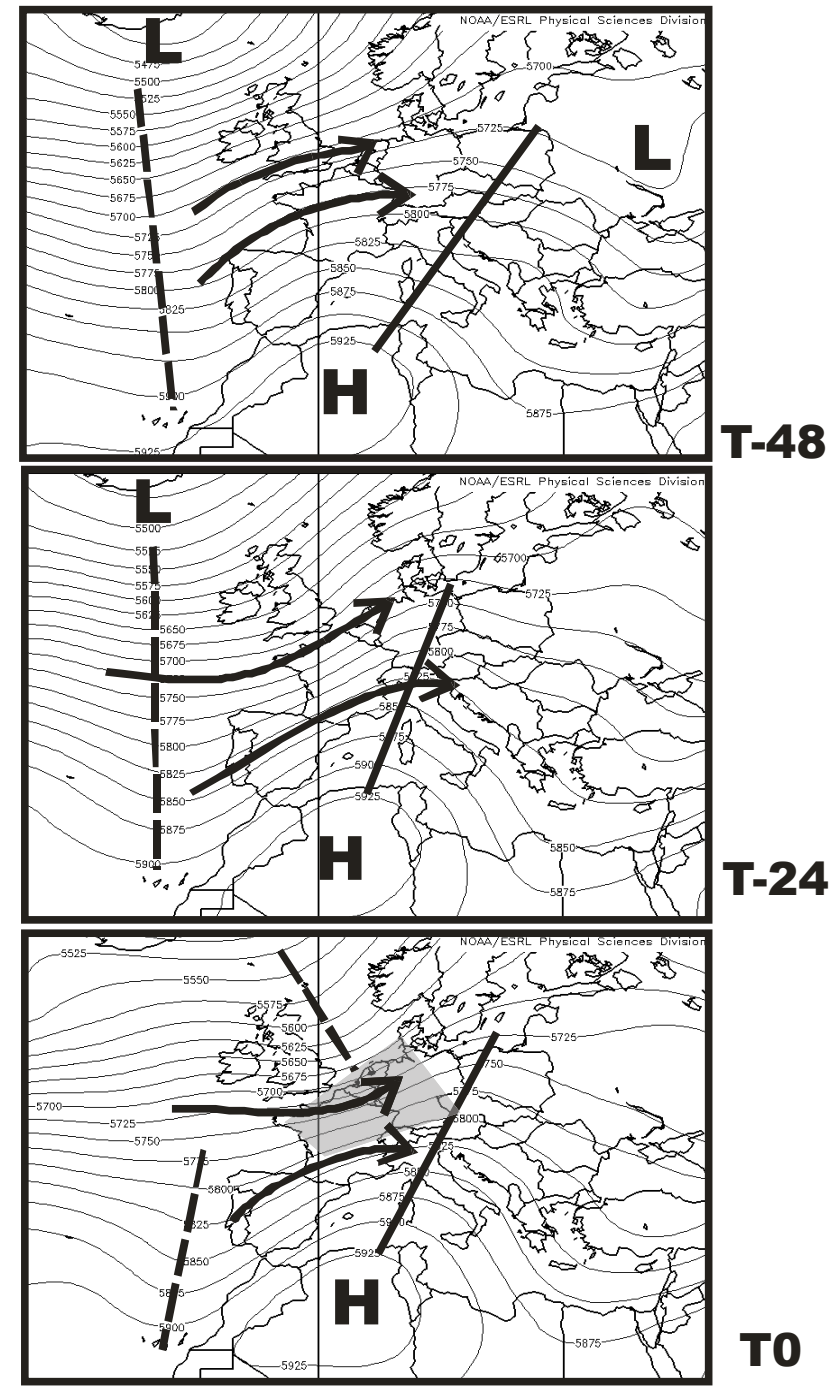

Figure 4. Composite time series at $500 \mathrm{hPa}$ for group one consisting of eight STH events. Heights contours at $100 \mathrm{gpm}$ are highlighted (contour interval is $25 \mathrm{gpm}$ ). Dashed lines indicate troughs while solid lines represent ridges in $500 \mathrm{hPa}$ flow. Arrows indicate flow trajectories and shading suggests areas where vertical motion would be expected with flow regime.

with a solid line in Fig. 4) extended well into central Europe and encompassed the entirety of the study area in the northeastern portion of Italy. A second synoptic-scale feature at T-48 was a low pressure (height) center at $60^{\circ} \mathrm{N}$ over the North Atlantic Ocean accompanied by a trough of lower geopotential heights extending southward (illustrated with a dashed line). $500 \mathrm{hPa}$ flow at the study site was dominated by westerly flow which followed height contours around the sub-tropical ridge.

Progressing to T-24 the closed low over the Atlantic remained stationary as the trough began to amplify southward. The sub-tropical high was still in place and geopotential heights proximal to the study site were maximized at 
$5825 \mathrm{gpm}$. Also at T-24 the downstream flow from the amplifying trough west of the sub-tropical ridge began to compress $500 \mathrm{hPa}$ height contours along the northwestern flank of the sub-tropical ridge.

At T-0 the trough over the eastern Atlantic began to fill, however a short-wave trough formed (dashed line) over the central portion of the continent at approximately $5-15^{\circ} \mathrm{E}$ (the area is shaded for emphasis in Fig. 4). The short wave translated east and eroded the northwest flank of the sub-tropical ridge, lowering geopotential heights associated with this stationary feature. This also introduced positive vorticity advection (not shown in figures) of 10 to $30 \mathrm{~ms}^{-1}$ in conjunction with the short-wave circulation. The $500 \mathrm{hPa}$ flow over the study area at T- 0 became more southwesterly as the subtropical ridge was impacted by the short wave. The compressed contour lines at $500 \mathrm{hPa}$ as well as the positive vorticity associated with the short wave created an upper-air configuration that supported vertical motion $(700 \mathrm{hPa}$ omega of $-0.06 \mathrm{~Pa} \mathrm{~s}^{-1}$ was observed across meso- $\alpha$ study area) and intense convective rainfall in the region of the debris flow basins for the eight STH events. Omega is a calculated atmospheric parameter based on observation of both temperature advection and vorticity advection. The magnitude of omega is based on the magnitude of these two atmospheric observations. In general warm air advection and positive vorticity advection coinciding in space and time produces a negative omega value which suggests upward vertical motion.

\section{$5.2500 \mathrm{hPa}$ geopotential height composites - amplifying low group}

The $500 \mathrm{hPa}$ composite plots for the second group was calculated from only two events, 20 September 1999 and 30 September 2000. As these two events occurred in September their commonality may be the result of processes related to seasonal transition. The dominate synoptic-scale feature in the composite for this group was a deep $500 \mathrm{hPa}$ trough across most of southern Europe associated with a surface frontal boundary. This type of synoptic setting would be less likely in the early or mid-summer months in the Mediterranean region with the dominant sub-tropical high well established. September however can be a transitional month in the region as the Mediterranean climate shifts from dry phase (summer) to wet phase (winter). This group of two events was the only group dominated by a broad synopticscale trough thus the group will be referred to as the amplifying low group or AL for ease of discussion.

In the AL composite the sub-tropical high-pressure ridge was displaced both southward and eastward of its summer season position. Lower geopotential heights were also observed from 45 to $55^{\circ} \mathrm{N}$ across eastern Europe. Downstream a weak area of higher geopotential heights stacked above a closed low forming a high-over-low blocking configuration at approximately $20^{\circ} \mathrm{E}$. However the most prominent synoptic-scale feature was a deep closed low (5400 gpm)

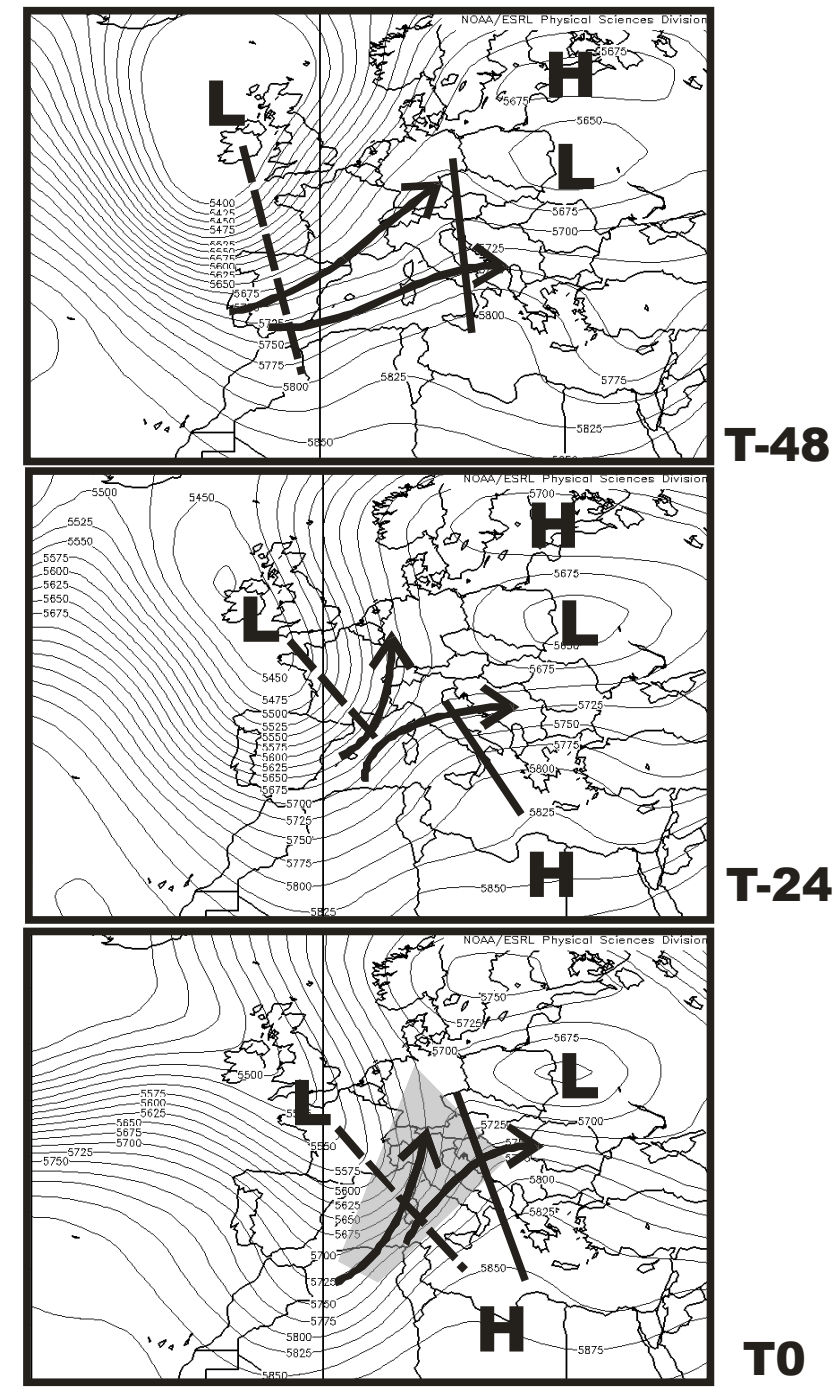

Figure 5. Composite time series at $500 \mathrm{hPa}$ for group two consisting of two AL events. Heights contours at 100 gpm are highlighted (contour interval is $25 \mathrm{gpm}$ ). Dashed lines indicate troughs while solid lines represent ridges in $500 \mathrm{hPa}$ flow. Arrows indicate flow trajectories and shading suggests areas where vertical motion would be expected with flow regime.

over the British Isles with a negatively tilted trough extended into northwestern Africa at T-48 (Fig. 5).

At T-24 the low-pressure trough across western Europe deepened into the Mediterranean region and the positive tilt of the trough became more apparent. The high-over-low blocking configuration to the east (downstream) of the amplifying trough remained stationary and encumbered the eastward translation of the low-pressure feature thus intensifying the trough to ridge flow (active region flow) at $500 \mathrm{hPa}$ north of $45^{\circ} \mathrm{N}$. Upper-air flow over the study area shifted to southerly at T-24 and the study area was located in the intensifying active region of the synoptic-scale flow. This area of strong divergent flow has the potential to enhance vertical 
motion and this in turn could encourage convection over a large area.

By T- 0 the trough deepened, extending across southern Europe. The downstream blocking configuration impeded eastward translation and encouraged a more pronounced negative tilt of the trough and thus the southeasterly amplification of the feature. $500 \mathrm{hPa}$ flow across northern Italy at $\mathrm{T}-0$ was southerly and upper-level divergence associated with the active region of the flow pattern created an environment that supported strong vertical motion $(700 \mathrm{hPa}$ omega calculated at $-0.30 \mathrm{~Pa} \mathrm{~s}^{-1}$ ) and convection across the study area.

\section{$5.3500 \mathrm{hPa}$ geopotential height composites - high-over-low block group}

The final group also consisted of only two events: 28 July 1999 and 4 July 2011. These two events exhibited a high-over-low blocking configuration in the region of the debris flow basins and will be referred to as the HL group.

At T-48 the most prominent features apparent in the HL composite were two adjacent synoptic-scale troughs, one off the coast of Portugal and the other east of the study area (Fig. 6). These two areas of lower geopotential heights were separated by a narrow ridge at the prime meridian which was the northernmost expression of the sub-tropical ridge emanating from northern Africa. The westernmost trough forms a "cut-off" from the geostrophic flow at T-48 and $500 \mathrm{hPa}$ flow into the study region at is encumbered by a highly amplified trough over the western portion of the synoptic domain.

At T-24 the cut-off low at $500 \mathrm{hPa}$ progressed eastward. This eastward translation accompanied the weakening and filling of the area of lower geopotential heights over eastern Europe. With this weakening of the downstream obstacle the cut-off low translated eastward and effectively undercut the northern portion of the ridge at $10^{\circ} \mathrm{E}$. This stacked configuration at $500 \mathrm{hPa}$ defines a mature high-over-low blocking regime. Mature phase in this case refers to the nearly vertical (north-south) alignment of the poleward cut-off high and the cut-off low equatorward of the high. In this phase, translation of the wave flow at $500 \mathrm{hPa}$ is highly encumbered giving rise to the term "block".

The T- 0 composite revealed that the high-over-low blocking configuration had shifted into central Europe and the low, of the high-over-low block, was positioned proximal to the debris flow study area. The advancing low compressed the remnants of the subtropical high which had subsided to approximately $40^{\circ} \mathrm{N}$. Immediately to the north of the low the high began to strengthen and the blocking configuration is clearly visible in the geopotential height contours. Circulation about the stationary low in the blocking regime resulted in counter-clockwise flow at $500 \mathrm{hPa}$ across central and northern Italy and positive vorticity of $15 \mathrm{~ms}^{-1}$ advected into the study area contributing to vigorous vertical motion (700 hPa omega of $-0.15 \mathrm{~Pa} \mathrm{~s}^{-1}$ ) across northeastern Italy.

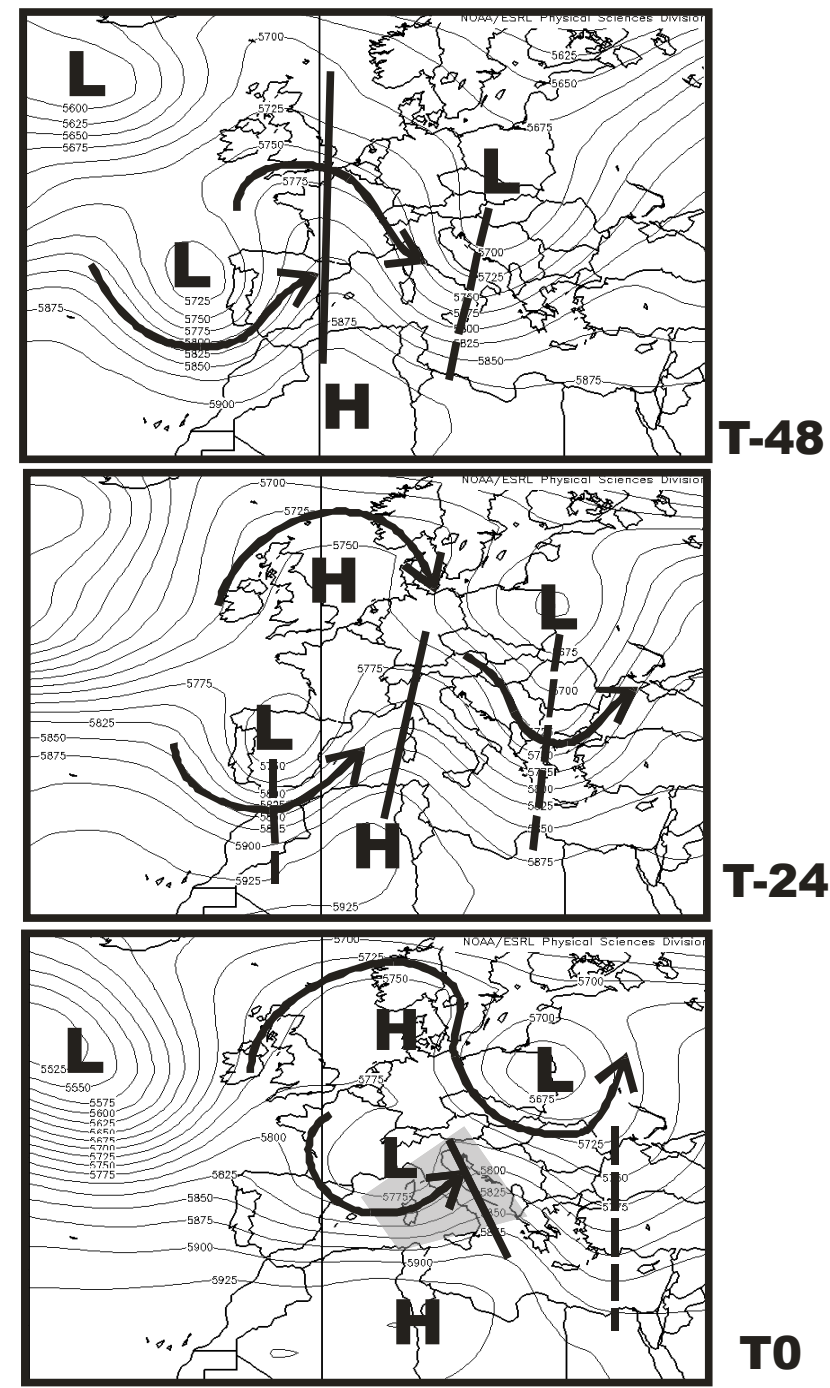

Figure 6. Composite time series at $500 \mathrm{hPa}$ for group three consisting of two HL events. Heights contours at $100 \mathrm{gpm}$ are highlighted (contour interval is $25 \mathrm{gpm}$ ). Dashed lines indicate troughs while solid lines represent ridges in $500 \mathrm{hPa}$ flow. Arrows indicate flow trajectories and shading suggests areas where vertical motion would be expected with flow regime.

\section{Multi-scale CG flash and rainfall analysis}

In this section a summary of CF flash and rainfall statistics are presented at both the meso- $\alpha$ and meso- $\beta$ spatial scales over multiple temporal scales. Additionally time series analyses for each event are presented for CG flashes and rainfall for the $60 \mathrm{~min}$ "critical interval" prior to debris flow initiation - critical in that intense rainfall occurring during this period is the likely trigger for debris flow. Critical interval CG flashes are analyzed only at the meso- $\beta$ scale. Rainfall data for critical interval analysis was obtained from the gauge nearest the debris flow source region. The rainfall gauge is part of a meso-network of gauges installed across the basins 
Table 2. Summary of critical interval variables at meso- $\beta$ scale.

\begin{tabular}{|c|c|c|c|c|c|c|c|c|c|c|c|c|}
\hline & $\begin{array}{l}7 \text { Aug } \\
1996 \\
\text { STH }\end{array}$ & $\begin{array}{l}12 \text { Jun } \\
1997 \\
\text { STH }\end{array}$ & $\begin{array}{l}17 \text { Aug } \\
1998 \\
\text { STH }\end{array}$ & $\begin{array}{l}20 \mathrm{Jul} \\
1999 \\
\text { STH }\end{array}$ & $\begin{array}{l}\text { 30 Jun } \\
2001 \\
\text { STH }\end{array}$ & $\begin{array}{l}19 \mathrm{Jul} \\
2004 \\
\text { STH }\end{array}$ & $\begin{array}{l}18 \text { Aug } \\
2011 \\
\text { STH }\end{array}$ & $\begin{array}{l}5 \mathrm{Jul} \\
2006 \\
\text { STH }\end{array}$ & $\begin{array}{l}20 \mathrm{Sep} \\
1999 \\
\text { AL }\end{array}$ & $\begin{array}{l}30 \mathrm{Sep} \\
2000 \\
\mathrm{AL}\end{array}$ & $\begin{array}{l}28 \mathrm{Jul} \\
1999 \\
\mathrm{HL}\end{array}$ & $\begin{array}{l}4 \text { Jul } \\
2011 \\
\text { HL }\end{array}$ \\
\hline Total flash (CGF/60 min) & 66 & 201 & 18 & 0 & 1090 & 325 & 43 & 1037 & 152 & 1 & 35 & 119 \\
\hline Peak flash (CGF/5 min) & 14 & 36 & 5 & 0 & 131 & 42 & 10 & 140 & 24 & 1 & 18 & 19 \\
\hline Peak charge (-kA/5 min) & -78.6 & -156.7 & -42.8 & 0 & -74.0 & -128.4 & -70.0 & -75.3 & -40.5 & +85.7 & -46.6 & -112.3 \\
\hline Peak \% pos. (GGF/60 min) & 1.5 & 1.5 & 16.7 & 0 & 2.4 & 0.5 & 14.0 & 1.4 & 22.5 & 100 & 0 & 6.6 \\
\hline Total PPT (mm/60 min) & 25.4 & 23.0 & 27.6 & 19.6 & 19.0 & 12.2 & 16.8 & 44.8 & 12.0 & 16.4 & 33.2 & 21.6 \\
\hline PPT dur. (min/60 min) & 25 & 35 & 55 & 25 & 15 & 25 & 15 & 35 & 45 & 50 & 40 & 35 \\
\hline PPT int. $\left(\mathrm{mm} \mathrm{min}^{-1}\right)$ & 1.02 & 0.66 & 0.61 & 0.78 & 1.27 & 0.49 & 1.12 & 1.28 & 0.27 & 0.33 & 0.83 & 0.62 \\
\hline Peak PPT (PPT/5 min) & 11.8 & 5.2 & 8.1 & 7.9 & 10.4 & 6.6 & 8.2 & 12.4 & 2.0 & 6.7 & 10.2 & 5.4 \\
\hline Lifted index at $\mathrm{T}-0\left({ }^{\circ} \mathrm{C}\right)$ & -1.0 & -3.0 & -3.5 & -3.0 & -2.5 & 0.0 & -3.5 & -3.5 & 1.0 & 0.5 & -3.5 & 0.0 \\
\hline $500 \mathrm{hPa}(\mathrm{gpm})$ & 5810 & 5755 & 5835 & 5820 & 5835 & 5840 & 5865 & 5845 & 5700 & 5670 & 5775 & 5770 \\
\hline
\end{tabular}

and identified in Gregoretti and Dalla Fontana (2008) and Degetto et al. (2015). Analyzing meso- $\beta$ CG flashes and rainfall at the $60 \mathrm{~min}$ temporal scale is intended to further downscale the analysis to capture characteristics of local convective processes that generate LICR at the debris flow source region. This analysis is also intended to test the hypothesis of colocation of LICR with CG flashes in space and in time as found by previous studies undertaken in complex terrain (Batton, 1965; Holle and Bennett, 1997; Soriano et al., 2001; Underwood and Schultz, 2004; Underwood, 2006).

In discussing the results of the time series analysis there are multiple references to the meso- $\alpha$ flash pattern and the $6 \mathrm{~h}$ meso- $\beta$ flash sequence. The graphics for these analyses are not presented as figures but may be viewed in Supplements $\mathrm{S} 1$ and $\mathrm{S} 2$ linked to this paper.

Table 2 is a summary of observations and statistics related to both CG flashes and rainfall for each of the 12 events over the $60 \mathrm{~min}$ critical interval at the meso- $\beta$ scale. The events are listed in chronological order for each group. The variables related CG flashes and rainfall are analyzed at 5 min intervals. This temporal unit ( $5 \mathrm{~min}$ ) has proven valuable in analyzing lighting and hydro-meteorological phenomena in the past (Holle and Bennett, 1997; Lopez and Holle, 1986). The spatial unit over which the CG flash data are collected is $7850 \mathrm{~km}^{2}$ (meso- $\beta$ scale). This scale has also been utilized in prior research as an efficient spatial unit for relating CG flashes to basin-scale LICR and debris flow initiation (Underwood and Schultz, 2004). Two of the variables listed in Table 2, lifted index and $500 \mathrm{hPa}$ heights, are grid values extracted from the $2.5^{\circ}$ by $2.5^{\circ} \mathrm{NCEP}$ reanalysis upper-air grid encompassing the study area. A single grid value was extracted and is intended to represent the meso- $\beta$ scale estimates of these variables. The CG flash variable "polarity" identifies the charge of the discharge at the ground. Globally approximately $96 \%$ of CG flashes lower a negative charge and only about $4 \%$ lower positive charges. The polarity can be used as an indicator of where the flash originated in the cumulus cloud and in some cases suggests an elevated elec- tric field, as many positive CG flashes deliver a much more intense charge to the Earth's surface.

\subsection{Debris flow event of 7 August 1996}

The debris flow event of 7 August 1996 was synoptically classified as STH and produced a total of 9284 CG flashes at the meso- $\alpha$ scale over the event day $(24 \mathrm{~h})$. The $6 \mathrm{~h}$ period prior to debris flow saw $3239 \mathrm{CG}$ flashes at the meso- $\alpha$ scale and $79 \mathrm{CG}$ flashes at the meso- $\beta$ scale. For the $60 \mathrm{~min}$ interval preceding debris flow initiation there were $1724 \mathrm{CG}$ flashes at the meso- $\alpha$ scale but only $66 \mathrm{CG}$ flashes at the meso- $\beta$ scale. The flashes at the smaller spatial scale comprise only $4 \%$ of the meso- $\alpha$ total. Focusing the analysis at the meso- $\beta$ scale during the critical interval the $66 \mathrm{GG}$ flashes that were recorded proximal to the debris flow basin accounted for $84 \%$ of meso- $\beta$ flashes during the 6 hours prior to debris flow initiation.

A time series of CG flashes and rainfall during the critical interval for the event occurring on 7 August 1996 is presented in Fig. 7. The debris flow in this case occurred during the 5 min interval ending at 19:00 UTC. The peak 5 min flash rate (14 CGF $5 \mathrm{~min}^{-1}$ ) occurred at 18:40 UTC and was the only flash peak recorded during the critical interval. Multiple CG flash peak were observed post debris flow. Peak 5 min rainfall of $11.8 \mathrm{~mm}$ preceded the peak CG flash rate by $10 \mathrm{~min}$, occurring at 18:30 UTC. Rainfall accumulated quickly during this event with a total of $25.4 \mathrm{~mm}$ of rainfall occurring between 18:25 and 18:45 UTC. Critical interval rainfall intensity for this event was estimated at $1.02 \mathrm{~mm} \mathrm{~min}^{-1}$.

This event exhibited temporal and spatial colocation of CG flashes and rainfall at the meso- $\beta$ scale. The co-located CG flashes and LICR occurred in the form of a "burst" during a longer CG flash sequence.

\subsection{Debris flow event of 12 June 1997}

The debris flow event of 12 June 1997 was prolific in terms of total CG flashes. Over the $24 \mathrm{~h}$ event day $15765 \mathrm{CG}$ flashes were recorded across the meso- $\alpha$ domain. However, only 


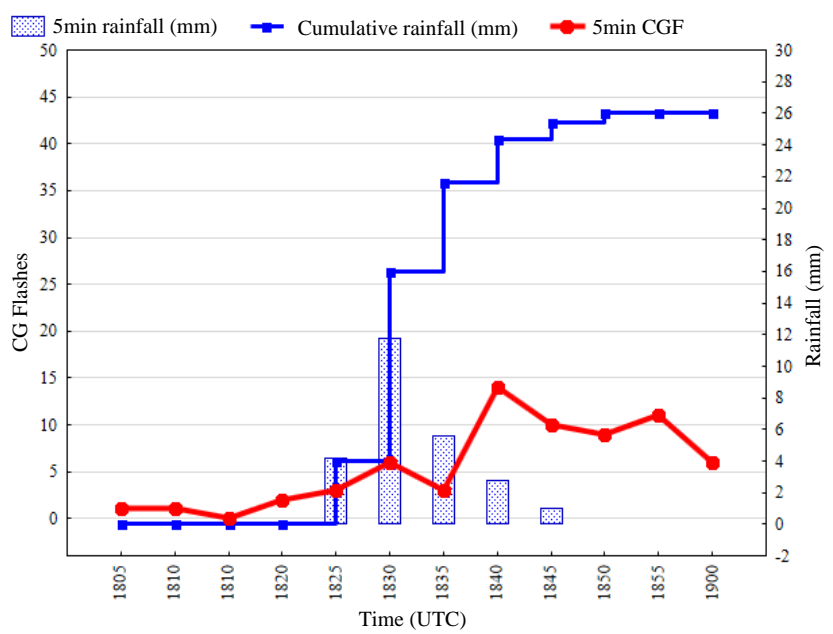

Figure 7. Critical interval time series for debris flow event of $7 \mathrm{Au}-$ gust 1996. This is an event from the STH group and debris flow initiation was observed at 19:00 UTC.

860 of these meso- $\alpha$ scale CG flashes occurred during the $6 \mathrm{~h}$ period preceding the debris flow. A total of 439 CG flashes, or $51 \%$ of these flashes, were observed at the meso- $\beta$ scale during the $6 \mathrm{~h}$ period preceding debris flow. During to the critical interval $201 \mathrm{CG}$ flashes occurred across the meso- $\beta$ analysis unit.

The critical interval sequence for this event suggests that the peak 5 min rainfall rate and the peak 5 min CG flash rate were coincident in time at the meso- $\beta$ scale, occurring at 12:55 UTC, which was $25 \mathrm{~min}$ prior to debris flow initiation (Fig. 8). Rainfall accumulated to $23.0 \mathrm{~mm}$ during the critical interval and rainfall intensity was estimated at $0.66 \mathrm{~mm} \mathrm{~min}^{-1}$ prior to the debris flow. The lifted index for this case suggests an unstable lower troposphere with an observed value of $-3.0^{\circ} \mathrm{C}$. Although this event saw a large number of CG flashes across the meso- $\beta$ domain in the $6 \mathrm{~h}$ preceding debris flow, the CG flash peak was synchronized with maximum rainfall intensity which occurred during the critical interval. From Supplement S2, one can note that there were two previous CG flash peaks prior to the critical interval but neither of these peaks were associated with significant rainfall at the debris source region.

\subsection{Debris flow event of 17 August 1998}

For the debris flow event of 17 August 1998 the $24 \mathrm{~h}$ flash count at the meso- $\alpha$ scale was 11037 and 4887 (44\%) of these CG flashes occurred within the 6 hours preceding the observed debris flow. At the meso- $\beta$ scale CG flashes totaled 347 for the $6 \mathrm{~h}$ period preceding the debris flow. The low CG flash frequency at the meso- $\beta$ scale was further illustrated in the $60 \mathrm{~min}$ critical interval where only 24 CG flashes were recorded.

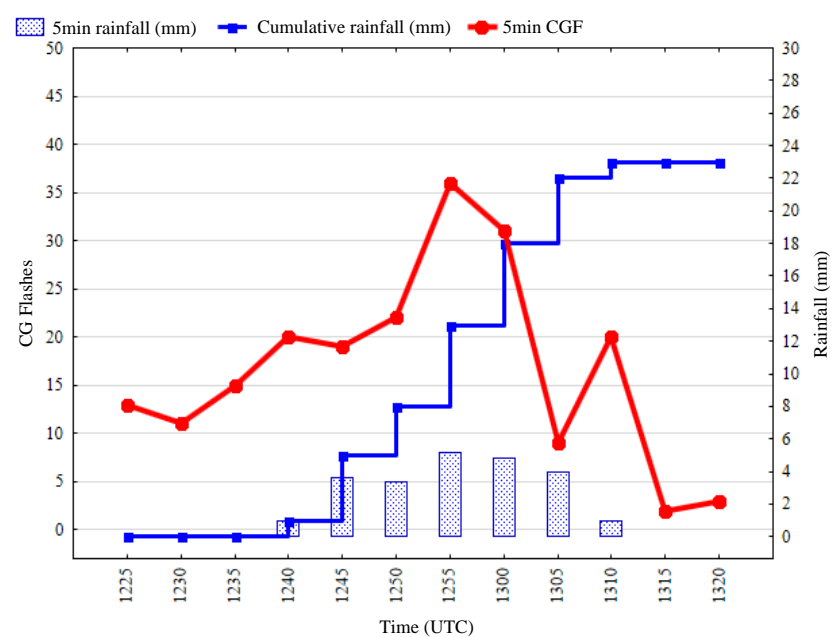

Figure 8. Critical interval time series for debris flow event of 12 June 1997. This is an event from the STH group and debris flow initiation was observed at 13:20 UTC.

Even though the CG flash sequence in the critical interval produced few $\mathrm{CG}$ flashes, the total accumulated rainfall during the critical interval was $27.6 \mathrm{~mm}$. The $5 \mathrm{~min}$ rainfall rate peaked at $8.1 \mathrm{~mm}$ just $15 \mathrm{~min}$ prior to debris flow initiation. Rainfall was recorded continuously for $45 \mathrm{~min}$ and rainfall intensity was calculated at $0.50 \mathrm{~mm} \mathrm{~min}^{-1}$ (Fig. 9). The lifted index for this event was $-3.5^{\circ} \mathrm{C}$ suggesting an unstable environment across northern Italy with the potential for intense convection across the study domain.

This event was unique in that the critical interval represented the final CG flashes of an extensive flash sequence lasting $310 \mathrm{~min}$ (Supplement S2). The mean $5 \mathrm{~min}$ flash frequency for the sequence was $6.1 \mathrm{CGF} 5 \mathrm{~min}^{-1}$ with a standard deviation $4.8 \mathrm{CGF} 5 \mathrm{~min}^{-1}$. The lower CG flash frequency during the critical interval coupled with the rapid accumulation of rainfall during this period suggests that instability may have been released over a prolonged period as $1.27 \mathrm{~mm}$ rainfall did accumulate at the debris flow basin prior to the critical interval.

\subsection{Debris flow event of 20 July 1999}

The $24 \mathrm{~h} \mathrm{CG}$ flash total at the meso- $\alpha$ scale for the event occurring on 20 July 1999 was 2312 , which was the lowest total of the 12 events. However, 1286 CG flashes occurred within 6 hours prior to debris flow initiation. At the meso- $\beta$ scale 505 CG flashes occurred within 6 hours of debris flow initiation; however, no flashes occurred within $60 \mathrm{~min}$ critical interval.

Figure 10 is a depiction of the critical interval time series for the debris flow event of 20 July 1999. As previously stated, there were no CG flashes during this period however $19.6 \mathrm{~mm}$ of rainfall accumulated during the $60 \mathrm{~min}$ leading up to the debris flow initiation. The peak 5 min rain- 


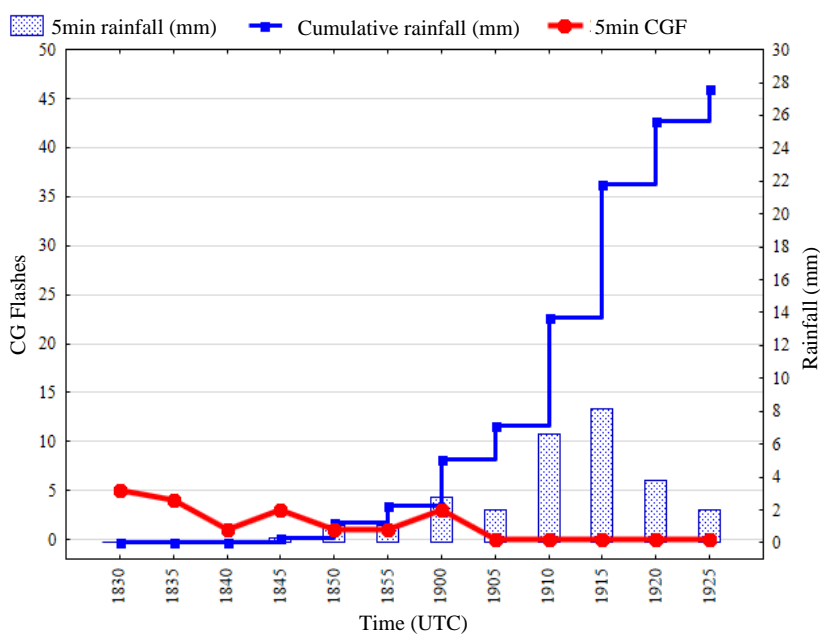

Figure 9. Critical interval time series for debris flow event of $17 \mathrm{Au}-$ gust 1998. This is an event from the STH group and debris flow initiation was observed at 19:25 UTC.

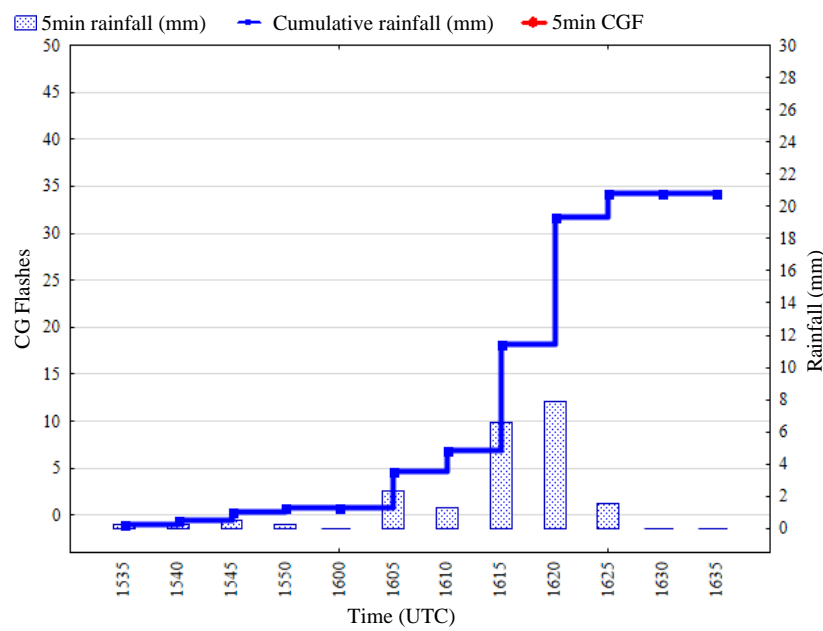

Figure 10. Critical interval time series for debris flow event of 20 July 1999. This is an event from the STH group and debris flow initiation was observed at 16:35 UTC.

fall of $7.9 \mathrm{~mm}$ was recorded at 16:20 UTC $15 \mathrm{~min}$ prior to debris flow. Rainfall intensity for the event was calculated at $0.78 \mathrm{~mm} \mathrm{~min}^{-1}$. The lifted index across the northern portion of Italy was -3.0 and this is another case where there was sufficient convective instability across the region to produce both CG flashes and LICR. As with the previous events there was a prolific CG flash sequence at the meso- $\beta$ scale prior to the critical interval, including numerous peaks greater than one standard deviation above the mean CG flash frequency of 11.2 CGF $5 \mathrm{~min}^{-1}$ (Supplement S2).

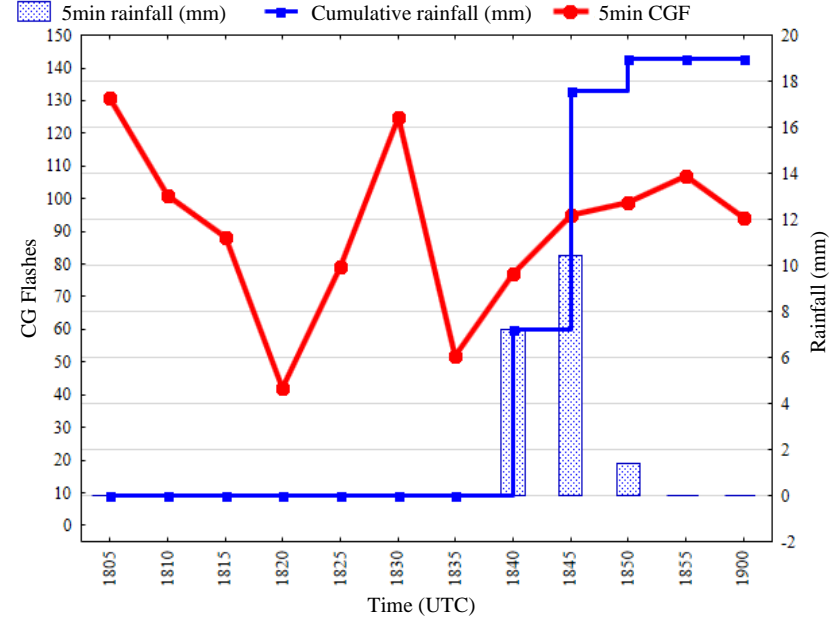

Figure 11. Critical interval time series for debris flow event of 30 June 2001. This is an event from the STH group and debris flow initiation was observed at 19:00 UTC.

\subsection{Debris flow event of 30 June 2001}

Event day 30 June 2001 produced a 24 h CG flash total of 12483 at the meso- $\alpha$ scale. The $6 \mathrm{~h} \mathrm{CG}$ flash total prior to debris flow at this scale was 5413 which constituted $43 \%$ of all meso- $\alpha$ scale flashes. At the meso- $\beta$ scale the 6 hours preceding debris flow initiation saw 1523 CG flashes and 1090 of these CG flashes ( $72 \%$ ) occurred during the critical interval.

The critical interval for this event experienced the three prolific 5 min peaks in CG flash activity (Supplement S2). This case conforms to the assumption of peak CG flash activity coinciding in space and time with peak rainfall intensity. The peaks in CG flash frequency were confined to a period beginning $15 \mathrm{~min}$ prior to the critical interval and ending 15 min post critical interval.

Figure 11 focuses the analysis on the critical interval and illustrates the CG flash peak of $131 \mathrm{CGF} 5 \mathrm{~min}^{-1}$ at 18:05 UTC. There were also two additional peaks in CG flash activity during the $60 \mathrm{~min}$ period, one at 18:30 UTC where 125 CG flashes were recorded and another at 18:55 UTC with 107 CG flashes. Total rainfall for the event was recorded over a short span of time during the critical interval. The rainfall burst for this event occurred in concert with increasing CG flash activity. Peak rainfall of $10.4 \mathrm{~mm}$ was recorded $15 \mathrm{~min}$ prior to the observed debris flow. The debris flow was generated during the $5 \mathrm{~min}$ interval ending at 19:00 UTC which also coincided with a period of increased CG flash activity. Total accumulated rainfall for the $60 \mathrm{~min}$ critical interval was $19.0 \mathrm{~mm}$ and the rainfall intensity was calculated at $1.27 \mathrm{~mm} \mathrm{~min}^{-1}$ making this one of the most intense rainfall events in the 12-member population. The lifted index at T-0 for the event was $-2.5^{\circ} \mathrm{C}$ indicating ample instability across the region to support widespread and intense convection. The 


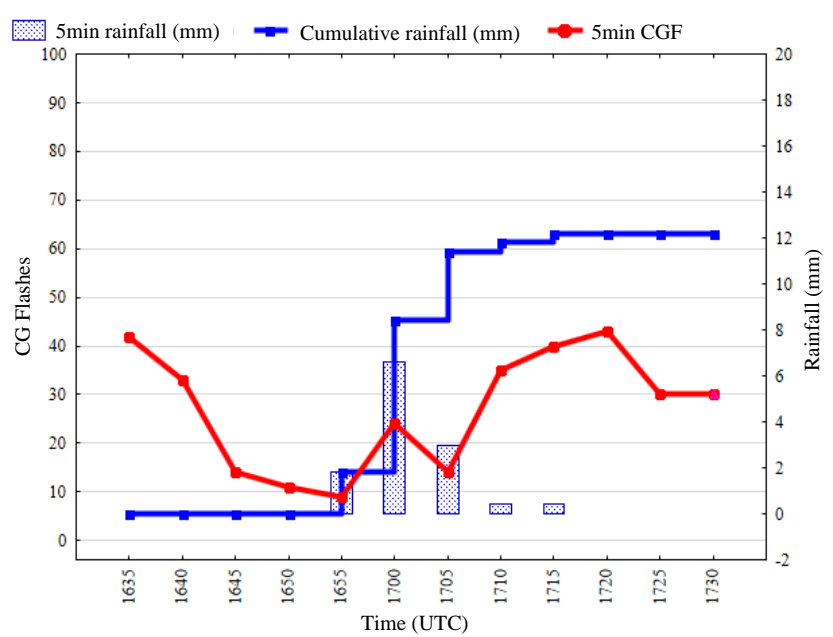

Figure 12. Critical interval time series for debris flow event of 19 July 2004. This is an event from the STH group and debris flow initiation was observed at 17:30 UTC.

CG flash composite (Supplement S1) for this event illustrates that convection (as represented by CG flashes) was prolific at the meso- $\alpha$ scale and concentrated in clusters proximal to debris flow basins.

\subsection{Debris flow event of 19 July 2004}

The $24 \mathrm{~h}$ meso- $\alpha$ scale CG flash total for the debris flow event of 19 July 2004 was 7464 . The composite flash plot (Supplement S1) shows that nearly all CG flashes were confined to the northeastern corner of the meso- $\alpha$ analysis domain. $81 \%$ (6071) of the meso- $\alpha$ flashes occurred during the 6 hours preceding the observed debris flow. Of those 6071 CG flashes 1473 occurred at the smaller meso- $\beta$ scale during the $6 \mathrm{~h}$ period. During the critical interval $325 \mathrm{CG}$ flashes were observed at the meso- $\beta$ scale.

Focusing on the critical interval Fig. 12 illustrates the rapid accumulation of rainfall between 16:55 and 17:05 UTC. Peak $5 \mathrm{~min}$ rainfall of $6.6 \mathrm{~mm}$ was recorded during this period. Total rainfall accumulating during the critical interval was $12.2 \mathrm{~mm}$. Rainfall intensity for the event was calculated at $0.49 \mathrm{~mm} \mathrm{~min}^{-1}$. No rainfall was recorded for the first $20 \mathrm{~min}$ of the critical interval even though a peak CG flash frequency of 42 CGF $5 \mathrm{~min}^{-1}$ was recorded at 16:35 UTC. CG flashes continued for the duration of the critical interval with a second flash peak of 43 CGF $5 \mathrm{~min}^{-1}$ occurring at 17:20 UTC.

This event saw multiple peaks in CG flashes at the meso- $\beta$ scale prior to the critical interval as well as CG flash peaks post debris flow. A high-frequency CG flash activity was apparent for most of 400 min flash sequence at the meso- $\beta$ scale; however, there was no record of antecedent rainfall at the debris flow basin (Supplement S2).

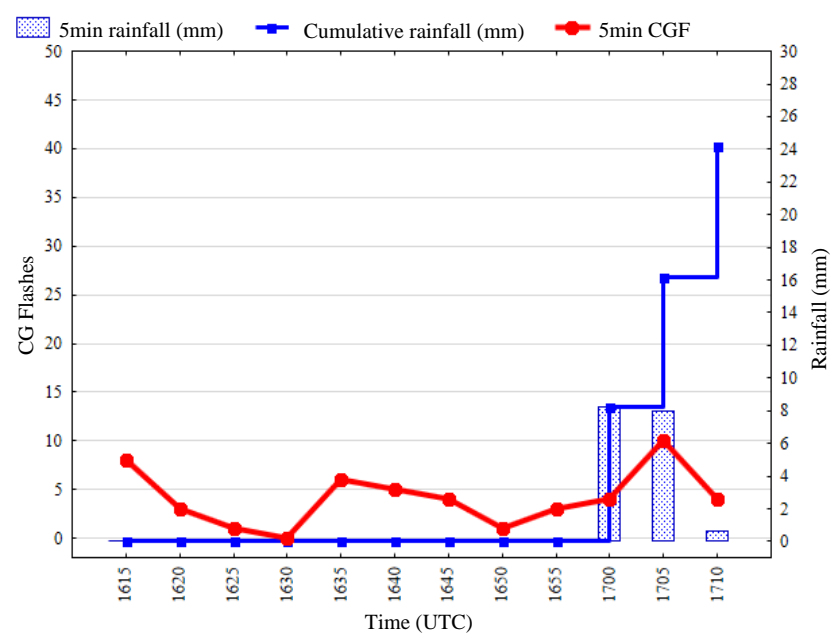

Figure 13. Critical interval time series for debris flow event of 18 August 2011. This is an event from the STH group and debris flow initiation was observed at 17:10 UTC.

\subsection{Debris flow event of 18 August 2011}

The debris flow event of 18 August 2011 produced a $24 \mathrm{~h}$ event-day total of $6851 \mathrm{CG}$ flashes over the meso- $\alpha$ analysis domain. Of these flashes at the meso- $\alpha$ scale only $647(9 \%)$ occurred during the $6 \mathrm{~h}$ immediately preceding the reported debris flow. Further, only $157 \mathrm{CG}$ flashes occurred at the meso- $\beta$ scale during the $6 \mathrm{~h}$ period, 43 of these during the critical interval. The flash composite located in Supplement S1 shows a banding of CG flashes from southwest to northeast in the upper left quadrant of the meso- $\alpha$ analysis domain and a very limited cluster of flashes isolated near the meso- $\beta$ study area.

During the critical interval at the meso- $\beta$ scale, total rainfall accumulated to $16.8 \mathrm{~mm}$ falling primarily in a $10 \mathrm{~min}$ burst leading to debris flow initiation which occurred at 17:10 UTC. Peak rainfall was recorded at 17:00 UTC as $8.2 \mathrm{~mm}$. Rainfall intensity for the event was $1.12 \mathrm{~mm} \mathrm{~min}^{-1}$. The lifted index for this event was $-3.5^{\circ} \mathrm{C}$ suggesting atmospheric instability across northern Italy. Figure 13 illustrates the temporal distribution of the $43 \mathrm{CG}$ flashes that occurred during the critical interval. There were two peaks in CG flashes during the critical interval, one at 16:15 UTC, another at 17:05 UTC. The peak in CG flash frequency at 17:05 UTC coincided with the $10 \mathrm{~min}$ burst of rainfall $(16.2 \mathrm{~mm})$ that triggered the debris flow at 17:10 UTC.

The longest sequence of continuous CG flashes at the meso- $\beta$ scale lasted 245 min with mean 5 min flash frequency of $4.0 \mathrm{CGF} 5 \mathrm{~min}^{-1}$ and a standard deviation of 3.4 CGF $5 \mathrm{~min}^{-1}$ (Supplement S2). During this flash sequence there were only two peaks in CG flash activity outside the critical interval and both were more than $120 \mathrm{~min}$ prior to the debris flow initiation. 


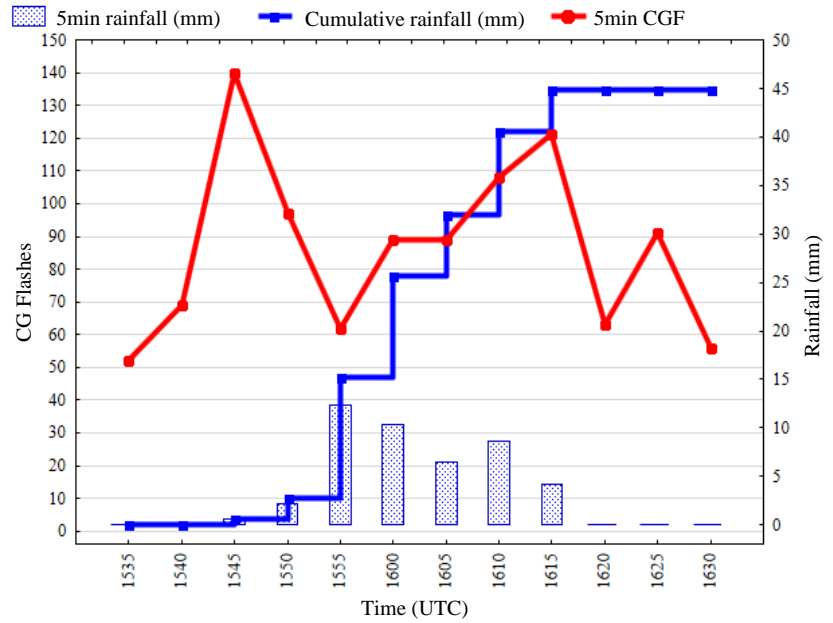

Figure 14. Critical interval time series for debris flow event of 5 July 2006. This is an event from the STH group and debris flow initiation was observed at 16:30 UTC.

\subsection{Debris flow event of 5 July 2006}

The 5 July 2006 event was prolific in terms of total CG flashes over the $24 \mathrm{~h}$ of the debris flow event-day. A total of $14150 \mathrm{CG}$ flashes were recorded across the meso- $\alpha$ scale for the event. CG flashes at the meso- $\alpha$ scale were confined to the western and north-central portion of the analysis domain and were organized in bands stretching from southwest to northeast (Supplement S1).

During the 6 hours leading up to debris flow initiation 6035 CG flashes occurred at the meso- $\alpha$ scale. During this same $6 \mathrm{~h}$ period $1650 \mathrm{CG}$ flashes occurred at the more compact meso- $\beta$ scale which covers $7850 \mathrm{~km}^{2}$ immediately surrounding the debris flow basins. During the critical interval a total of $1037 \mathrm{CG}$ flashes occurred at the meso- $\beta$ scale.

Critical interval CG flash activity peaked at 140 in a single 5 min period (15:45 UTC) and coincided with the first measured rainfall for the case. CG flash activity continued at high frequency throughout the critical interval as rainfall became more intense.

Peak rainfall was realized at 15:55 UTC with $12.4 \mathrm{~mm}$ recorded during this $5 \mathrm{~min}$ interval. Rainfall accumulation for the case was $44.8 \mathrm{~mm}$ at the gauging station adjacent to the debris flow source region and this was the highest rainfall total of any case in the population. Rainfall accumulated over a period of $35 \mathrm{~min}$ and the rainfall intensity was calculated at $1.28 \mathrm{~mm} \mathrm{~min}^{-1}$.

Figure 14 illustrates both the continuous high-frequency CG flash activity and the rapid accumulation of rainfall at the debris flow site. This particular critical interval time series illustrates the close temporal and spatial colocation of CG flashes and LICR in the complex terrain of the study area. The seven CG flash peaks embedded in the critical interval represented the most intense flash frequencies recorded,

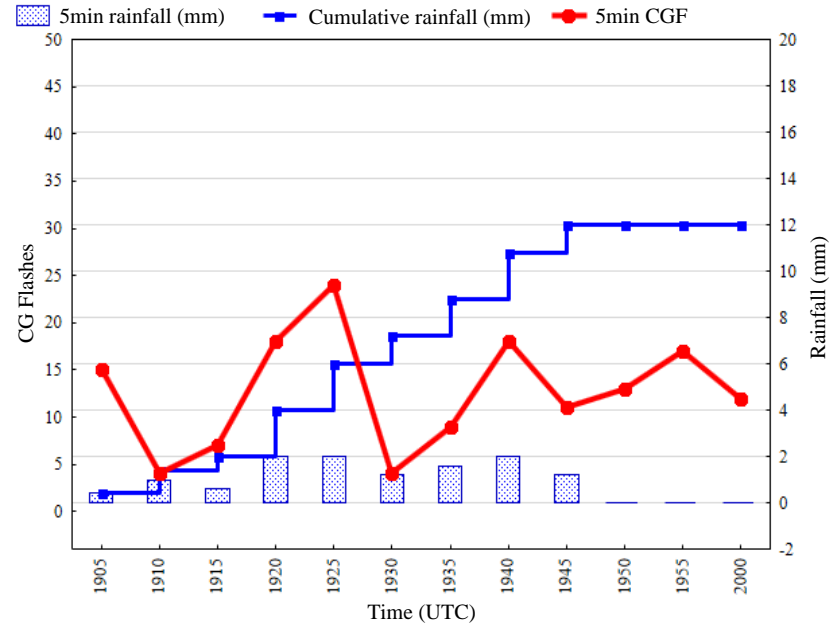

Figure 15. Critical interval time series for debris flow event of 20 September 1999. This is an event from the AL group and debris flow initiation was observed at 20:00 UTC.

and the peaks were temporally positioned in the center of the 300 min CG flash sequence at the meso- $\beta$ scale (Supplement S2).

\subsection{Debris flow event of 20 September 1999}

The $24 \mathrm{~h}$ flash total for the event occurring on 20 September 1999 was 3637 CG flashes at the meso- $\alpha$ scale. The flashes for this event were spatially disconnected, consisting of three primary clusters and a diffuse pattern of flashes over the meso- $\beta$ scale analysis domain. This pattern suggests that there may have been multiple forcing mechanisms for convective activity during the event-day (Supplement S1). The 6 hours preceding the debris flow saw 789 CG flashes at the meso- $\alpha$ scale. This case produced few CG flashes at the meso- $\beta$ scale (178) during the 6 hours preceding the debris flow. Of the $178 \mathrm{CG}$ flashes in the meso- $\beta$ domain, $152(85 \%)$ of these flashes occurred during the critical interval.

During the critical interval a total of $12.0 \mathrm{~mm}$ of rainfall accumulated at the gauge proximal to the debris flow source region. This rainfall accumulated over a $45 \mathrm{~min}$ period from 19:05 to 19:45 UTC, ceasing 15 min prior to the debris flow which occurred at 20:00 UTC. Rainfall intensity for the event was calculated at only $0.27 \mathrm{~mm} \mathrm{~min}^{-1}$, the lowest intensity among the 12 events in the population. Peak 5 min rainfall for this case was $2.0 \mathrm{~mm}$ but rainfall accumulated steadily to the $12.0 \mathrm{~mm}$ total during the critical interval. The most intense CG flash peak (24 CGF $5 \mathrm{~min}^{-1}$ ) occurred during the critical interval at 19:25 UTC. Three other CG flash peaks were recorded, the first at 19:20 UTC (18CGF $\left.5 \mathrm{~min}^{-1}\right)$, a third at 19:40 UTC also at 18 CG flashes and a final peak of 17 CG flashes 19:55 UTC which was 5 min prior to debris flow initiation (Fig. 15). 
Four CG flash peaks were recorded during the critical interval. The critical interval occurred late in the evening of the event-day and was temporally centered in a flash sequence lasting $95 \mathrm{~min}$. The mean flash frequency for this sequence was $9.2 \mathrm{CGF} 5 \mathrm{~min}^{-1}$ and the standard deviation was 6.5 CGF $5 \mathrm{~min}^{-1}$. Even though rainfall intensity was not extreme in this case the rainfall was collocated with the peaks in CG flash activity and proximal in space and time to debris flow initiation.

\subsection{Debris flow event of 30 September 2000}

The event that occurred on 30 September 2000 was unusual as a total of 4613 CG flashes were recorded at the meso$\alpha$ scale for the $24 \mathrm{~h}$ event-day. At the same scale $303 \mathrm{CG}$ flashes occurred during the 6 hours preceding debris flow initiation. The CG flash pattern as illustrated in Supplement S1 revealed that nearly all CG flashes occurred in the region of the Adriatic Sea well south of the meso- $\beta$ scale study area. The flashes were in a single cluster elongated from north to south and suggests intense convection; however, this convection (as represented by CG flashes) was not spatially collocated with rainfall at the debris flow basins.

At the meso- $\beta$ scale only one CG flash occurred during the 6 hours preceding debris flow initiation and this single flash occurred during the critical interval during the same $5 \mathrm{~min}$ interval of the reported debris flow. This single flash was also unique in that it lowered a positive charge to the ground $(+85.7 \mathrm{kA})$. There were no extended CG flash sequences associated with this case.

Another unique characteristic of this case was the duration of rainfall during the critical interval. This was the only case in the population in which rainfall was recorded for the entire $60 \mathrm{~min}$ of the critical interval. Rainfall intensity was $0.33 \mathrm{~mm} \mathrm{~min}^{-1}$ for the case and peak $5 \mathrm{~min}$ rainfall of $6.7 \mathrm{~mm}$ occurred at $16: 35 \mathrm{UTC}, 15 \mathrm{~min}$ in advance of the debris flow. In Fig. 16 one can visualize the flat line representing CG flash observations and the long-duration rainfall that characterized the case. The lack of colocation of CG flashes and rainfall, the continuous nature of the rainfall and the spatial pattern of CG flashes may be the result of the synoptic-scale circulation pattern observed during this event. This was a case dominated by an amplifying trough (AL event type) and a surface frontal boundary. Rainfall along a frontal boundary can be light and occur over an extended period. In cases of frontal lift it is not uncommon for CG flashes and rainfall to be quite distant from one another in space and time.

\subsection{Debris flow event of 28 July 1999}

The debris flow event of 28 July 1999 produced the highest $24 \mathrm{~h}$ CG flash total of the 12 event population. A total of 19586 CG flashes occurred across the meso- $\alpha$ domain for the event-day. The CG flashes were distributed across

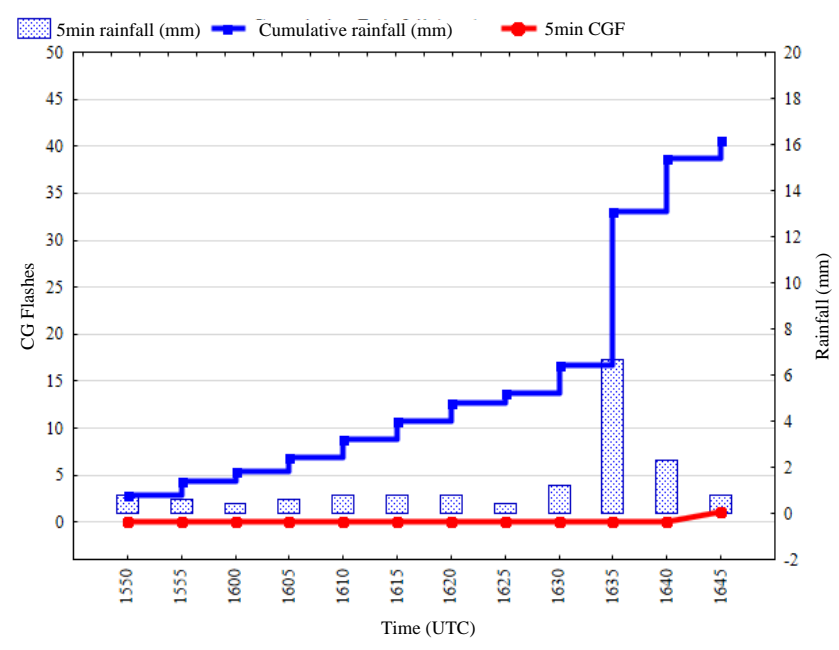

Figure 16. Critical interval time series for debris flow event of 30 September 2000. This is an event from the AL group and debris flow initiation was observed at 16:45 UTC.

the entirety of the meso- $\alpha$ scale analysis domain with more dense clusters of flashes in the southern portion - south of the meso- $\beta$ scale analysis unit. There was however a single dense CG flash cluster inside the smaller study domain (Supplement S1).

Of the 19586 CG flashes 8640 (44\%) occurred within 6 hours of debris flow initiation at the meso- $\alpha$ scale. At the meso- $\beta$ scale during the 6 hours preceding the debris flow only 425 CG flashes were recorded and during the critical interval at the meso- $\beta$ scale 35 CG flashes were observed.

The debris flow case of 28 July 1999 produced total rainfall of $33.2 \mathrm{~mm}$ and peak $5 \mathrm{~min}$ rainfall of $10.2 \mathrm{~mm}$ at 14:30 UTC. Rainfall intensity was calculated at $0.83 \mathrm{~mm} \mathrm{~min}^{-1}$ and rainfall occurred for 40 continuous minutes prior to debris flow initiation. The lifted index was estimated at $-3.5^{\circ} \mathrm{C}$ which suggests an unstable lower troposphere and the potential for widespread convection, which is evidenced by the CG flash pattern in Supplement S1.

Though very few CG flashes were recorded during the critical interval, the analysis of the interval illustrates an example of LICR occurring synchronously with a peak in CG flash frequency. Rainfall began to accumulate quickly from 14:15 to 14:35 UTC with a peak at 14:30 UTC. This rainfall peak $\left(10.2 \mathrm{~mm}\right.$ ) lagged the CG flash peak (18 CGF $5 \mathrm{~min}^{-1}$ ) by only $5 \mathrm{~min}$ and preceded the debris flow by $10 \mathrm{~min}$. At the time of debris flow initiation both CG flash frequency and rainfall rate were decreasing from their respective peaks (Fig. 17).

At the meso- $\beta$ scale a 565 min continuous CG flash sequence was recorded with mean $\mathrm{CG}$ flash frequency of 6.9 CGF $5 \mathrm{~min}^{-1}$ and a standard deviation calculated at 7.8 CGF $5 \mathrm{~min}^{-1}$. There were a number of flash peaks observed during this sequence. The only period during the 565 min sequence when CG flash frequency dropped to zero 


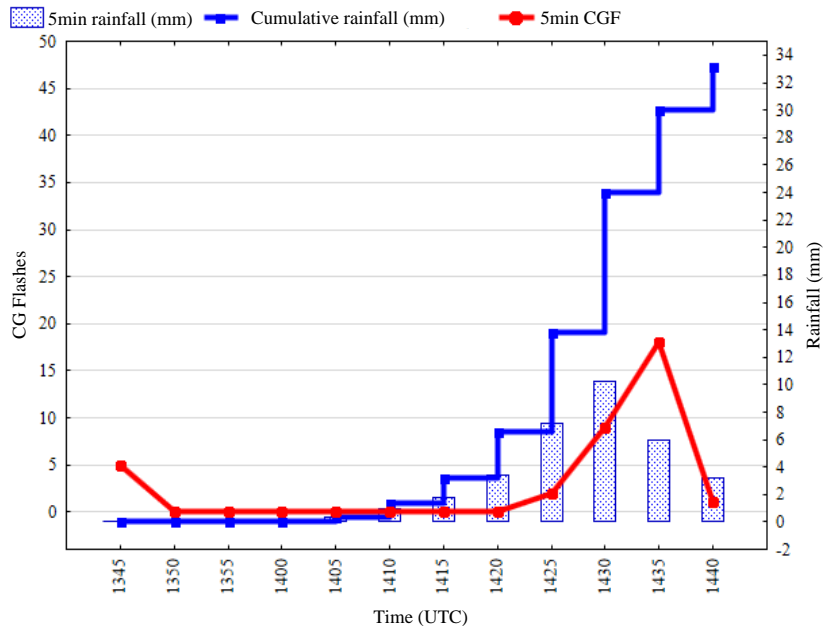

Figure 17. Critical interval time series for debris flow event of 28 July 1999. This is an event from the HL group and debris flow initiation was observed at 14:40 UTC.

was during the critical interval prior to the onset of rainfall at the debris flow basin (Supplement S2). However the critical interval saw a coinciding peak in CG flashes and rainfall prior to debris flow initiation.

\subsection{Debris flow event of 4 July 2011}

The CG flash total for this event was 7609 for the $24 \mathrm{~h}$ period over which flashes were observed at the meso- $\alpha$ scale. Of this total $4760 \mathrm{CG}$ flashes occurred at the meso- $\alpha$ scale during the 6 hours preceding the debris flow on 4 July 2011. During the event-day CG flashes were primarily clustered in the southwest corner and of the meso- $\alpha$ analysis domain. An arching cluster however does intersect the meso- $\beta$ domain during the event-day (Supplement S1).

At the meso- $\beta$ scale 202 CG flashes occurred during the $6 \mathrm{~h}$ period leading up to the debris flow and $103 \mathrm{CG}$ flashes occurred during the critical interval. The critical interval experienced three CG flash peaks. The three peaks in CG flash frequency during the critical interval represented the highest flash frequencies prior to debris flow and were embedded in a $340 \mathrm{~min}$ flash sequence at the meso- $\beta$ scale. The most prolific peaks were two consecutive $5 \mathrm{~min}$ intervals (20:05 and 20:10 UTC) with CG flash frequencies of 19 CG flashes per $5 \mathrm{~min}$. A third peak was observed synchronously with debris flow initiation. There were numerous peaks in CG flash frequency post debris flow (Supplement S2). Mean CG flash frequency for the $340 \mathrm{~min}$ sequence was $8.5 \mathrm{CGF} 5 \mathrm{~min}^{-1}$ with a standard deviation of $6.6 \mathrm{CG} 5 \mathrm{~min}^{-1}$.

Total rainfall accumulation during the critical interval was $21.6 \mathrm{~mm}$ and peak $5 \mathrm{~min}$ rainfall was $5.4 \mathrm{~mm}$ recorded at 20:40 UTC which was 5 min prior to debris flow initiation. Rainfall intensity for the case was $0.62 \mathrm{~mm} \mathrm{~min}^{-1}$. Figure 18 illustrates the peak CG flash sequence preceding LICR by

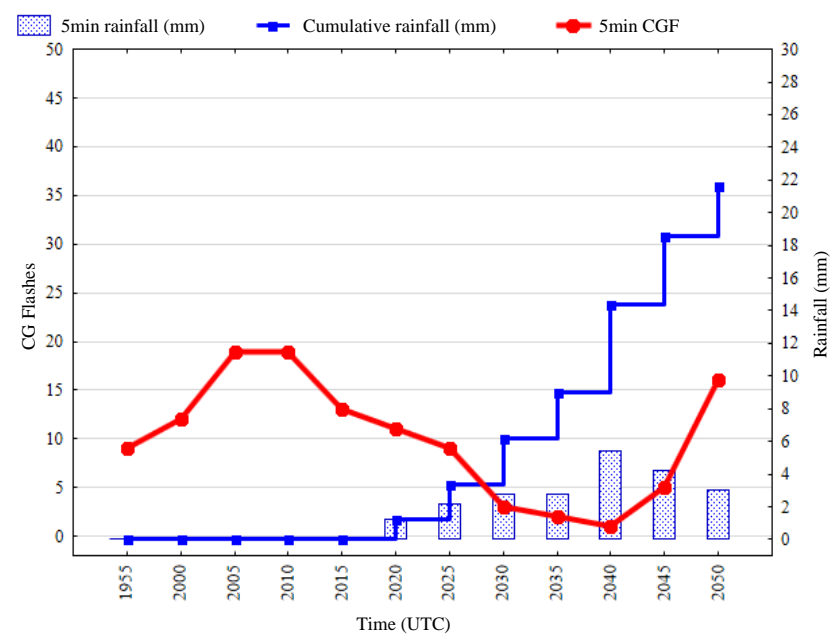

Figure 18. Critical interval time series for debris flow event of 4 July 2011. This is an event from the HL group and debris flow initiation was observed at 20:50 UTC.

10 min and the rapid accumulation of rainfall at the debris flow basin prior to the triggering of the debris flow at 20:50 UTC.

\subsection{Correlation analysis}

In order to identify statistical relationships between rainfall intensity at the debris flow source region and variables representing CG flash characteristics a Pearson product-moment correlation analysis was performed at the 0.05 level of significance (Hinkle et al., 2009). Variables were paired with rainfall intensity $\left(\mathrm{mm} \mathrm{min}^{-1}\right)$ since intensity of precipitation is both a triggering mechanism for debris flow and the variable most commonly utilized to warn of impending debris flows. Rainfall rates were converted to $\mathrm{mm} \mathrm{min}^{-1}$ as these are the units used in estimating rainfall intensity thresholds for debris flow initiation in previous studies. Rainfall intensity observations and CG flash variables were observed at the meso- $\beta$ scale during the $60 \mathrm{~min}$ critical interval. Variables characterizing local-scale atmospheric stability (lifted index and $500 \mathrm{hPa}$ geopotential heights) were collected from the T- 0 observation for the $2.5^{\circ} \times 2.5^{\circ}$ grid encompassing the study area. Paired variables that resulted in significant Pearson " $r$ " statistics were assumed to be related in a linear fashion. All CG flash and atmospheric variables listed in Table 2 were analyzed and the statistically significant relationships (at $p$ value 0.05 ) are listed below:

- rainfall intensity $\left(\mathrm{mm} \mathrm{min}^{-1}\right)$ vs. total $60 \mathrm{~min} \mathrm{CG}$ flashes, $r=0.61$;

- rainfall intensity $\left(\mathrm{mm} \mathrm{min}^{-1}\right)$ vs. peak $5 \mathrm{~min}$ CG flash rate, $r=0.62$; 
- rainfall intensity $\left(\mathrm{mm} \mathrm{min}^{-1}\right)$ vs. lifted index $\left({ }^{\circ} \mathrm{C}\right)$, $r=-0.67$

- rainfall intensity $\left(\mathrm{mm} \mathrm{min}^{-1}\right)$ vs. $500 \mathrm{hPa}$ height (gpm), $r=0.72$.

Two very clear signals emerged from the correlation analysis. First, rainfall intensity at the debris flow site was related to the larger scale atmospheric environment as was suggested by the significant relationships between this variable and lifted index observations as well as $500 \mathrm{hPa}$ geopotential heights. The negative $r$ value associated with lifted index reflects the fact that a more unstable atmospheric environment produces negative LI values. The strong linear relationship between $500 \mathrm{hPa}$ heights and rainfall intensity suggests that the geopotential heights across much of the $2.5^{\circ} \times 2.5^{\circ}$ grid remained quite high at T- 0 even as the migratory lowpressure features described in sections above advected into the study area.

The correlation results also illustrate that as one downscales the analysis using meso- $\beta$ CG flash variables there is also a strong and significant linear relationship to rainfall intensity. In this case two variables, total CG flashes and peak five minute CG flash rate were significantly correlated with rainfall intensity. This confirms what was seen in a number of the time series plots where increased CG flash frequencies occurred synchronously with intense rainfall at the meso- $\beta$ scale. The significant relationships revealed by the correlation analysis suggest that there are in fact multi-scale processes interacting to produce LICR and thus debris flows in this particular study region.

\subsection{Lead-time analysis}

The lead-time analysis, as used in previous studies (Underwood and Schultz, 2004), calculates the time by which the peak value of an observed variable precedes debris flow initiation. In this case the mean lead-time was calculated for selected variables for the population of 12 events and organized by the three synoptic classifications (STH, AL, and $\mathrm{HL}$ ). This analysis was limited to the $60 \mathrm{~min}$ critical interval at the meso- $\beta$ scale.

Results of the lead-time analysis are presented for peak rainfall intensity since this variable is used with great frequency as a debris-triggering threshold and warning parameter for debris flow initiation (Moody and Martin, 2001). In addition to rainfall intensity two CG flash variables are presented: peak CG flash rate (CGF $5 \mathrm{~min}^{-1}$ ) and peak CG flash intensity $\left(\mathrm{kA} 5 \mathrm{~min}^{-1}\right)$. These particular CG flash variables were the only variables to produce mean lead-times that exceeded the lead-time calculated for peak rainfall intensity.

The mean lead-time calculated for rainfall intensity across the population of 12 events was $-21 \mathrm{~min}$. The mean leadtime for peak CG flash rate was $-35 \mathrm{~min}$, therefore outperforming rainfall intensity by $14 \mathrm{~min}$ (outperforming in terms of providing a longer lead-time from observed peak to debris flow initiation). The mean lead-time calculated for peak CG flash intensity across the population of events was $-32 \mathrm{~min}$, again outperforming mean lead-time for peak rainfall rate as a precursor for debris flow initiation for the 12 events. The lead-time calculated for peak CG flashes using only the STH events was $-43 \mathrm{~min}$ and peak CG flash intensity calculated for only the two events in HL group was -48 min. A summary of the lead-time analysis is presented below:

- mean lead-time Peak Rainfall Rate to Debris Flow Initiation (all events): $-21 \mathrm{~min}$;

- mean lead-time Peak Rainfall Rate to Debris Flow Initiation (STH events): $-23 \mathrm{~min}$;

- mean lead-time Peak Rainfall Rate to Debris Flow Initiation (AL events): $-25 \mathrm{~min}$;

- mean lead-time Peak Rainfall Rate to Debris Flow Initiation (HL events): $-7.5 \mathrm{~min}$;

- mean lead-time Peak CG Flash Rate to Debris Flow Initiation (all events): $-35 \mathrm{~min}$;

- mean lead-time Peak CG Flash Rate to Debris Flow Initiation (STH events): $-43 \mathrm{~min}$;

- mean lead-time Peak CG Flash Rate to Debris Flow Initiation (AL events): $-18 \mathrm{~min}$;

- mean lead-time Peak CG Flash Rate to Debris Flow Initiation (HL events): $-23 \mathrm{~min}$;

- mean lead-time Peak CG Flash Intensity to Debris Flow Initiation (all events): $-32 \mathrm{~min}$;

- mean lead-time Peak CG Flash Intensity to Debris Flow Initiation (STH events): $-31 \mathrm{~min}$;

- mean lead-time Peak CG Flash Intensity to Debris Flow Initiation (AL events): $-0 \mathrm{~min}$;

- mean lead-time Peak CG Flash Intensity to Debris Flow Initiation (HL events): $-48 \mathrm{~min}$.

It should be noted that the AL and HL groups consisted of only two events so the findings may be suspect. The more robust findings lie with the population means which suggests that when there are CG flashes present at the meso- $\beta$ scale both peak CG flash rate and peak CG flash intensity outperform rainfall intensity in terms of providing longer leadtimes.

The lead-time analyses are not purported to be "threshold" values that can be universally applied to predict impending debris flows. These peak values are intended to be indicators of the temporal relationship between CG flash characteristics and debris flow initiation. It is hoped that these relationships will provide guidance for further research that will produce more effective alert parameters for the debris flow hazard. 


\section{General discussion and conclusions}

This study analyzed 12 well documented debris flow events that occurred from 1996 through 2011 at five adjacent basin in the Dolomite Alps of northeastern Italy. In a unique experiment, multi-scale atmospheric variables were used to analyze the preconditions for LICR and debris flow initiation in this region of complex terrain. The particular advance that this research intended was an extended scale (both spatial and temporal) for debris flow analysis. Two hypotheses were tested in the study. The first suggested that there are common synoptic-scale atmospheric patterns that create a convective environment for LICR and thus debris flow initiation. A second hypothesis declared that CG flashes and LICR are collocated in space and time during the period immediately preceding debris flow initiation.

The two hypotheses posed were both answered in the affirmative. There were three distinct synoptic-scale patterns identified in advance of LICR and debris flow at the study site in northeastern Italy. The three patterns were defined by their flow regimes at the $500 \mathrm{hPa}$ pressure level and each pattern suggested the presence tropospheric processes that encourage vertical motion in the atmosphere proximal to the study site. Type one consisted of an established sub-tropical highpressure ridge in place over most of southern Europe which was subsequently eroded by a transitory short wave. Type two occurred later in the season (September) and consisted of an amplifying synoptic-scale trough associated with a surface frontal boundary. Type three was defined by a high-overlow blocking configuration aligned at approximately $10^{\circ} \mathrm{E}$, with the cut-off low portion of the block becoming stationary proximal to the study area. The authors assert that there may be other synoptic-scale patterns that promote LICR and debris flows in this region and are in no way suggesting that the three patterns identified represent the complete population of patterns. Data used to analyze the synoptic patterns have limitations as applied. The analysis used a small subset of atmospheric variables purposefully to keep simple the classifications. Multiple variables at various pressure levels are available from NCAR for analysis and further studies may want to use these variables as well as soundings to calculate stability indices for the region. The inclusion of sounding data would provide insight into the convective environment and allow a more refined examination of processes related to surface heating, atmospheric moisture, and parcel ascent.

The meso-scale analysis incorporated in the study produced summary statistics for CG flash sequences and rainfall variables. The highest event-day CG flash count across the meso- $\alpha$ domain was 19586 flashes and this occurred with the event of 28 July 1999 which was classified as an HL event. The second most prolific event-day was 12 June 1997 with 15765 CG flashes. This particular event was classified synoptically as STH. These extreme flash totals occurred only during events synoptically classified as STH and HL. The two events classified as AL produced substantially fewer CG flashes over the event-day and the bulk of these flashes were clustered well away from the meso- $\beta$ scale study area. This implies that late-season amplifying low-pressure features associated with surface frontal boundaries produce a CG flash sequence that are quite different from the summer season synoptic-scale patterns. The AL classified events were shown to lack colocation of CG flashes and LICR at the meso- $\beta$ study domain which is not an uncommon outcome of storm systems with a long linear boundary as the primary lifting feature.

The second hypothesis was confirmed using time series analysis and correlation analysis. The study found spatial and temporal colocation of CG flashes and LICR during the critical interval at the meso- $\beta$ scale in nine of the 12 events. Additionally there were statistically significant linear relationships between total CG flashes and rainfall intensity as well as peak 5 min CG flash frequency and rainfall intensity during the critical interval preceding debris flow initiation.

It is clear from the outcome of the synoptic-scale composite analysis that transitory low-pressure features interacting with a sub-tropical ridge were prolific in setting the stage for widespread convection across the meso- $\alpha$ scale. This was evidenced by both the number of CG flashes over the eventdays and the spatial distribution of CG flashes across the study region (Supplement S1). The time series and correlation analysis suggested that in addition to the broad-scale instability imposed by the transitory low-pressure features at $500 \mathrm{hPa}$ that convection was enhanced in the meso- $\beta$ analysis domain encompassing the debris flow basins. Enhanced release of convective energy as seen in the 12 CG flash plots and time series was evidenced in the fact that nine of the 12 events analyzed realized at least one peak in CG flash frequency during the critical interval at the meso- $\beta$ scale and three of the events saw the event-day maximum flash peak during the $60 \mathrm{~min}$ immediately preceding debris flow initiation. Additionally all 12 events recorded event-day maximum rainfall intensity during the critical interval. The enhancement of convection seen in the nine events may have been the result of regional orography. Other possible processes that could enhance convection in the area proximal to the debris source region are surface heating on south-facing slopes and the advection of excessive moisture into the region from adjacent water bodies; however, identifying the source/process of the enhancement was beyond the scope of this study.

The findings also suggest that one can downscale the analysis from the synoptic scale to smaller spatial and temporal scales using CG flash variables and this downscaling provides evidence of the synchronous relationship between CG flashes and LICR. In three of the 12 cases, the peak critical interval CG flash rate was realized during the same $5 \mathrm{~min}$ interval as peak rainfall intensity and in four other events peak CG flash rate occurred within $10 \mathrm{~min}$ of peak rainfall intensity. In all but one event peak CG flash rate occurred within 45 min of peak rainfall intensity. This colocation was con- 
firmed by the correlation analysis and lead-time analysis at the meso- $\beta$ scale.

The study focused much attention on the critical interval, defined as the $60 \mathrm{~min}$ preceding debris flow initiation, and the meso- $\beta$ scale, defined as the $7850 \mathrm{~km}^{2}$ area surrounding the debris flow basins. The critical interval analysis provided evidence that all events whether STH, AL, or HL produced LICR of ample intensity to trigger debris flows in this region of complex terrain. Rainfall intensity varied from 0.27 to $1.28 \mathrm{~mm} \mathrm{~min}^{-1}$ across the population of events. The critical intervals for 11 of the 12 events were embedded in CG flash sequences that ranged in duration from 95 to $565 \mathrm{~min}$. Also these 11 events produced extensive CG flashes both before and after the critical interval; however, the accumulation of rainfall in each event was sequestered to the $60 \mathrm{~min}$ critical interval. Only five events recorded antecedent rainfall and four events saw post debris flow rainfall. In each of these cases the antecedent and post debris flow rainfall was of lower intensity than that observed during the critical interval.

Findings from the study suggest that CG flashes at the meso- $\beta$ scale do act as good indicators for the onset of LICR and thus the triggering of debris flows. For example the events of 20 September 1999, 30 June 2001, and 5 July 2006 experienced peak event-day CG flash activity (at the meso- $\beta$ scale) during the critical interval and these flash peaks were coincident with peak rainfall intensity. Additionally, two CG flash variables - peak CG flash rate and peak CG flash intensity - provided lead-times greater than that afforded by peak rainfall intensity during the critical interval. These variables therefore have potential for analysis as alert parameters in the context of debris flow warnings and forecasts.

This research provides new insight into the multi-scale atmospheric processes preceding LICR and debris flow initiation in this unique part of the world where debris flows are extremely frequent. It is hoped that the findings from this research will promote the study of larger populations of debris flow events and prompt researchers to incorporate atmospheric variables in future studies of the debris flow hazard.

\section{Team members}

S. J. Underwood, M. D. Schultz, M. Berti, C. Gregoretti, A. Simoni, T. L. Mote, and A. M. Saylor.

\section{Copyright statement}

The author's copyright for this publication is transferred to Georgia Southern University, Statesboro, Georgia, USA.

\section{Data availability}

Atmospheric data used in this work are freely available from the US Department of Commerce, National Oceanic and Atmospheric Administration, Earth Systems Research Laboratory, Physical Sciences Division (http://www.esrl.noaa.gov/ psd/data/gridded/reanalysis/)

Lightning data incorporated in this work are proprietary and are the property of Centro Elettrotechnico Sperimentale Italiano - Sistema Italiano Rilevanmento Fulmini (CESISIRF), Milan, Italy

Rainfall data used in this work are the property of the authors and are available at Georgia Southern University Library open access portal (Digital Commons@GeorgiaSouthern).

\section{The Supplement related to this article is available online at doi:10.5194/nhess-16-509-2016-supplement.}

Author contributions. S. J. Underwood conceptualized the project, managed the project, designed the data collection and methodology, and produced the majority of text. M. D. Schultz was primary GIS analyst, responsible for quality control and analysis of geospatial data sets and production and analysis of data plots. M. Berti was primary contributor of geologic and geomorphic methods and background information related to study site, was also responsible for field deployment of instrumentation and collection of rainfall data, and collaborated in the production of text. C. Gregroetti was responsible for deployment of the field instrumentation and collection of rainfall data, provided data related to debris flow initiation at the study site, and collaborated in production of the text. A. Simoni assisted with deployment of instrumentation network and collection and distribution of field collected data sets. T. L. Mote was primary developer of the synoptic-scale analysis protocol and produced composite graphics to guide the analysis. A. M. Saylor assisted with GIS analysis including the development of case-specific statistics.

Acknowledgements. The authors would like to thank Centro Elettrotecnico Sperimentale Italiano - Sistema Rilevamento Fulmini (CESI-SIRF), Milan, Italy, and Marina Bernardi for providing cloud-to-ground lightning flash data for this publication.

Disclaimer. The content of this publication is the original work of the authors and has not been submitted for publication in any other outlet or venue.

Edited by: T. Glade

Reviewed by: T. Turkington and one anonymous referee 


\section{References}

Arattano, M.: On the use of seismic detectors as monitoring and warning systems for debris flows, Nat. Hazards, 20, 197-213, 1997.

Bacchini, M. and Zannoni, A.: Relations between Rainfall and Triggering of Debris-Flow: A Case Study of Cancia (Dolomites, Northeastern Italy), Nat. Hazards Earth Syst. Sci., 3, 71-79, doi:10.5194/nhess-3-71-2003, 2003.

Batton, L.: Some factors governing precipitation and lightning from convective clouds, Journal of Atmospheric Sciences, 22, 79-84, 1965.

Berti, M. and Simoni, A.: Experimental evidences and numerical modeling of debris flow initiated by runoff, Landslide, 2, 171$182,2005$.

Berti, M., Genevois, R., Simoni, A., and Tecca, R.: Field observations of a debris flow event in the Dolomites, Geomorphology, 29, 265-274, 1999.

Berti, M., Genevois, R., Simoni, A., and Tecca, P.: Debris flow monitoring in the Acquabona watershed on the Dolomites (Italian Alps), Phys. Chem. Earth, 9, 707-715, 2000.

Bodini, A. and Cossu, Q. A.: Vulnerability assessment of CentralEast Sardinia (Italy) to extreme rainfall events, Nat. Hazards Earth Syst. Sci., 10, 61-72, doi:10.5194/nhess-10-61-2010, 2010.

Cannon, S., Powers, P., and Savage, W.: Fire-related hyperconcentrated and debris flows on Storm King Mountain, Glenwood Springs, Colorado, USA, Environ. Geol., 35, 210-218, 1998.

Cannon, S., Gartner, J., Wilson, R., Bowers, J., and Laber, J.: Storm rainfall conditions for floods and debris flow from recently burned areas in southwestern Colorado and southern California, Geomorphology, 96, 250-269, 2008.

Chen, C., Chen, T., Yu, F., Yu, W., and Tseng, C.: Rainfall duration and debris-flow Initiation studies for real-time monitoring, Environ. Geol., 47, 715-724, 2005.

Chen, H., Zhang, L., Chang, D., and Zhang, S.: Mechanisms and runout characteristics of the rainfall-triggered debris flow in $\mathrm{Xi}$ aojiagou in Sichuan Province, China, Nat. Hazards, 62, 10371057, 2012.

Chen, J. C., Jan, C. D., and Huang, W. S.: Characteristics of rainfall triggering of debris flows in the Chenyulan watershed, Taiwan, Nat. Hazards Earth Syst. Sci., 13, 1015-1023, doi:10.5194/nhess-13-1015-2013, 2013.

Coe, J., Kinner, D., and Godt, J.: Initiation conditions for debris flows generated by runoff at Chalk Cliffs, central Colorado, Geomorphology, 96, 270-297, 2008.

Degetto, M., Greqoretti, C., and Bernard, M.: Comparative analysis of the difference between using LIDAR and contourbased DEMs for hydrological modeling of runoff generating debris flows in the Dolomites, Front. Earth Sci., 3, 21, doi:10.3389/feart.2015.00021, 2015.

DeGraff, J., Sidle, R., Ahmad, R., and Scatena, F.: Recognizing the importance of tropical forests in limiting rainfall-induced debris flows, Environ. Earth Sci., 67, 1225-1235, 2012.

Floris, M., D’Alpaos, A., Squarzoni, C., Genevois, R., and Marani, M.: Recent changes in rainfall characteristics and their influence on thresholds for debris flow triggering in the Dolomitic area of Cortina d'Ampezzo, north-eastern Italian Alps, Nat. Hazards
Earth Syst. Sci., 10, 571-580, doi:10.5194/nhess-10-571-2010, 2010.

Galgaro, A., Tecca, P. R., Genevois, R., and Deganutti, A. M.: Acoustic module of the Acquabona (Italy) debris flow monitoring system, Nat. Hazards Earth Syst. Sci., 5, 211-215, doi:10.5194/nhess-5-211-2005, 2005.

Gregoretti, C.: The initiation of debris flow at high slopes: experimental results, J. Hydraul. Res., 38, 83-88, 2000.

Gregoretti, C. and Dalla Fontana, G.: The triggering of debris flow due to channel-bed failure in some alpine headwater basins of the Dolomites: analysis of critical runoff, Hydrol. Process., 22, 2248-2263, 2008.

Hinkle, D., Wierma, W., and Jurs, S.: Applied Statistics for the Behavioral Sciences, 5th Edn., Wadsworth Publishing, Belmont, California, 2009.

Hoard, D. and Lee, J.: Synoptic classification of a ten-year record of $500 \mathrm{mb}$ weather maps for western United States, Meteorol. Atmos. Phys., 35, 96-102, 1986.

Holle, R. and Bennett, S.: Lightning ground flashes associated with summer 1990 flash Floods and streamflow in Tucson, Arizona: an exploratory study, Mon. Weather Rev., 125, 1526-1536, 1997.

Hunter, S., Underwood, S., Holle, R., and Mote, T.: Winter lightning and heavy frozen precipitation in the southeast United States, Weather Forecast., 16, 478-490, 2001.

Hurlimann, M., Abanco, C., Moya, J., and Vilajosana, I.: Results and experiences gathered at the Rebaixader debris-flow monitoring site, central Pyrenees, Spain, Landslides, 11, 939-953, 2014.

Imaizumi, F., Sidle, R., Tsuchiya, S., and Ohsaka, O.: Hydrogeomorphic processes in a steep debris flow initiation zone, Geophys. Res. Lett., 33, L10404, doi:10.1029/2006GL026250, 2006.

Iorio, R.: The Italian lightning detection system of CESI and its applications, Energia Elettrica, 75, 107-116, 1998.

Kalnay, E., Kanamitsu, M., Kistler, R., Collins, W., Deaven, D., Gandin, L., Iredell, M., Saha, S., White, G., Woollen, J., Zhu, Y., Chelliah, M., Ebisuzaki, W., Higgins, W., Janowiak, J., Mo, K., Ropelewski, C., Wang, J., Leetmaa, A., Reynolds, R., Jenne, R., and Joseph, D.: The NCEP/NCAR 40-year reanalysis project, B. Am. Meteorol. Soc., 77, 437-471, 1996.

Kaplan, M., Vellore, R., Lewis, J., Underwood, S., Pauley, P., Martin, J., and Krishman, R.: Re-examination of the interstate-5 dust storm, J. Geophys. Res., 118, 327-642, 2013.

Kean J., McCoy, S., Tucker, G., Staley, D., and Coe, J.: Runoffgenerated debris flows: observations and modeling of surge initiation, magnitude and frequency, J. Geophys. Res.-Earth, 118, 1-18, 2013.

Lapp, S., Byrne, J., Kienzle, S., and Townshend, I.: Linking global circulation model synoptics and precipitation for western North America, Int. J. Climatol., 22, 1807-1817, 2002.

Lopez, R. and Holle, R.: Diurnal and spatial variability of lightning activity in northeastern Colorado and central Florida during the summer, Mon. Weather Rev., 114, 1288-1312, 1986.

Marchi, L., Arattano, M., and Deganutti, A.: Ten years of debrisflow monitoring in the Moscardaro Torrent (Italian Alps), Geomorphology, 46, 1-17, 2002.

McCoy, S., Kean, J., Coe, J., Tucker, G., Staley, D., and Wasklewicz, T.: Sediment entrainment by debris flows: in situ measurements from the headwaters of a steep catchment, J. Geophys. Res., 117, $1-25,2012$. 
Moody, J. and Martin, D.: Post-fire, rainfall intensity-peak discharge relations for three mountainous watersheds in the western USA, Hydrol. Process., 15, 2981-2993, 2001.

Mote, T., Gamble, D., Underwood, S., and Bentley, M.: Synoptic scale features common to heavy snowstorms in the southeastern US, Weather Forecast., 12, 5-23, 1997.

Panizza, M.: Glacio-pressure implications in the production of landslides in the Dolomitic area, Geol. Appl. Idrogeol., 8, 289-297, 1973.

Parajka, J., Kohnova, S., Balint, G., Barbuc, M., Borga, M., Claps, P., Cheval, S., Dumitrescu, A., Gaume, E., Hlavcova, K., Merz, R., Pfaundler, M., Stancalie, G., Szolgay, J., and Bloschl, G.: Seasonal characteristics of flood regimes across the AlpineCarpathian range, J. Hydrol., 394, 78-89, 2010.

Rossa, A., Del Guerra, F., Borga, M., Zanon, F., Settin, T., and Leuenberger, D.: Radar-driven high resolution hydrometeorological forecasts of the 26 September 2007 Venice flash flood, J. Hydrol., 394, 230-244, 2010.

Schmidli, J., Goodess, C., Frei, C., Haylock, M., Hundecha, Y., Ribalaygua, J., and Schmith, T.: Statistical and dynamical downscaling of precipitation: An evaluation and comparison and comparison of scenarios for the European Alps, J. Geophys. Res., 112, 1-20, 2007.

Shieh, C., Chen, Y., Tsai, Y., and Wu, J.: Variability in rainfall threshold for debris flow after the Chi-Chi earthquake in central Taiwan, China, Int. J. Sediment Res., 24, 177-188, 2009

Soldati, M., Corsini, A., and Pasuto, A.: Landslides and climate change in the Italian Dolomites since the late glacial, Catena, 55, 141-161, 2004.

Soriano, L., de Pablo, F., and Diez, E.: Relationship between convective precipitation and cloud- to-ground lighting in the Iberian Peninsula, Mon. Weather Rev., 129, 2998-3003, 2001.

Staley, D. M., Kean, J., Cannon, S. H., Schmidt, K. M., and Laber, J. L.: Objective definition of rainfall-intensity thresholds for the initiation of post-fire debris flows in Southern California, Landslid, 10, 547-562, doi:10.1007/s10346-012-0341-9, 2013.

Tecca, P. and Genevois, R.: Field observations of the June 302001 debris flow at Acquabona (Dolomites, Italy), Landslides, 6, 3945, 2009.
Theule, J. I., Liébault, F., Loye, A., Laigle, D., and Jaboyedoff, M.: Sediment budget monitoring of debris-flow and bedload transport in the Manival Torrent, SE France, Nat. Hazards Earth Syst. Sci., 12, 731-749, doi:10.5194/nhess-12-731-2012, 2012.

Tognacca, C., Bezzola, G. R., and Minor, H. E.: Threshold criterion for debis-flow initiation due to channel-bed failure, in: Proc. of the 2nd Int. Conf. on Debris Flow, Hazards and Mitigation, Taipei, Taiwan, edited by: Wieczorek, G. F., A. A. Balkema, Rotterdam, 89-97, 2000.

Trapp, R., Diffenbaugh, N., and Gluhovsky, A.: Transient response of server thunderstorm forcing to elevated greenhouse gas concentrations, Geophys. Res. Lett., 36, L01703, doi:10.1029/2008GL036203, 2009.

Turkington, T., Ettema, J., van Westen, C. J., and Breinl, K.: Empirical atmospheric thresholds for debris flows and flash floods in the southern French Alps, Nat. Hazards Earth Syst. Sci., 14, 1517-1530, doi:10.5194/nhess-14-1517-2014, 2014.

Underwood, S.: Cloud-to-ground lightning flash parameters associated with heavy rainfall in the Denver, Colorado urban drainage and flood control district, Mon. Weather Rev., 134, 2566-2580, 2006.

Underwood, S. and Schultz, M.: Cloud-to-ground lightning flashes and debris flow generating rainfall in the post-wildfire environment: An exploratory study of the Mitchell Creek debris flow site in Colorado, J. Geophys. Res., 108, 108, 4567, doi:10.1029/2003JD003636, 2003.

Underwood, S. and Schultz, M.: Patterns of cloud-to-ground lightning associated with post wildfire flash floods and debris flows in complex terrain of the western US, J. Hydrometeorol., 5, 9891003, 2004.

Underwood, S., Kaplan, M., and King, K.: The role of upstream mid-tropospheric circulations enabling leeside precipitation in the Sierra Nevada, part one: A climatology of spillover precipitation and flooding in a lee-basin, J. Hydrometeorol., 10, 13091326, 2009. 